\title{
Vaux-en-Bugey (Ain, France): the first gas field produced in France, providing learning lessons for natural hydrogen in the sub-surface?
}

\author{
Jean-François Deronzier ${ }^{1, *}$ and Hélène Giouse ${ }^{2}$ \\ 1 JFDc, 6, rue de l'Essai, 75005 Paris, France \\ 2 97, rue Galliéni, 92500 Rueil-Malmaison, France
}

Received: 21 November 2018 / Accepted: 31 January 2020

\begin{abstract}
The former Vaux-en-Bugey field, first French methane production from early 20th century, is revisited as a case study to address the present generation and accumulation theories for gases like hydrogen and helium. The volume of the initial gas in place is estimated to be 22 million $\mathrm{m}^{3}$. Based on a composition of $5 \%$ of hydrogen and $0.096 \%$ of helium, the volumes of these gases in the field were respectively around 1.1 million $\mathrm{m}^{3}$ for hydrogen and $24000 \mathrm{~m}^{3}$ for helium. The different hypotheses of hydrogen sources are reviewed: serpentinization, hydro-oxidation of siderite, water radiolysis, bio-fermentation, mechanical generation, degassing from depth trough faults, steel corrosion. For helium generation, the different sources of radioactive minerals and intermediate accumulations are examined. The most probable scenario is the hydrogen production by water radiolysis and helium production by radioactive decay in or near the basement, migrating trough deep faults, stored and concentrating in an aquifer with thermogenic methane, then flushed by methane into the gas field, during Jura thrusting. New measurements with portable gas detector, incomplete but including hydrogen, on a former exploration well with accessible flux of gas, give the opportunity to comment gas saturation evolution more than a century after the 1906 discovery. The decreasing of hydrogen content since the discovery of the field is probably due to Sulphate-Reducing Bacteria activity.
\end{abstract}

Keywords: gas field / gas / natural hydrogen / helium / Jura / Bugey / Vaux-en-Bugey

Résumé - Vaux-en-Bugey (Ain, France): le premier gisement de gaz exploité en France, source d'enseignement sur l'hydrogène naturel dans le sous-sol ? L'ancien gisement méthane de Vaux-enBugey, première exploitation française du début du $\mathrm{XX}^{\mathrm{e}}$ siècle, est revisité comme cas d'étude pour confronter les théories actuelles de génération et accumulation de gaz tels que l'hydrogène et l'hélium, présents dans le gisement. Les roches mères de ces composés sont discutées ainsi que des hypothèses de mise en place et rétention. Le volume initial du gisement est estimé à 22 millions de $\mathrm{m}^{3}$. Sur la base d'une composition de $5 \%$ d'hydrogène et $0,096 \%$ d'hélium, les quantités accumulées dans le gisement pour ces deux gaz sont respectivement 1,1 millions de $\mathrm{m}^{3}$ pour l'hydrogène et $24000 \mathrm{~m}^{3}$ pour l'hélium. Les différentes hypothèses de sources de l'hydrogène sont revues: serpentinisation, hydro-oxydation de la sidérite, radiolyse de l'eau, bio-fermentation, génération par effet mécanique, dégazage de source profonde via des failles, corrosion de l'acier. Pour la génération d'hélium, les différentes sources de minéraux radioactifs et les accumulations intermédiaires sont également examinées. L'hypothèse la plus probable est la génération de l'hydrogène par radiolyse de l'eau et de l'hélium par radioactivité dans ou proche du socle, migrant par des failles profondes, s'accumulant et se concentrant dans un aquifère avec du méthane thermogénique puis entraînés avec le méthane dans le gisement lors du chevauchement du Jura. De nouvelles mesures gaz sur détecteur portable, partielles mais comprenant l'hydrogène, sur un des anciens puits forés présentant un flux gaz accessible, permet de commenter une évolution du composé gazeux plus de cent ans après la date de découverte en 1906. La diminution de la teneur en hydrogène depuis la découverte du gisement est probablement due à l'activité de bactéries sulfato-réductrices.

Mots clés : gisement / gaz / hydrogène naturel / hélium / Jura / Bugey / Vaux-en-Bugey

\footnotetext{
*Corresponding author: jf deronzier777@gmail.com
} 


\section{Introduction}

Hydrogen is an attracting fuel, because it does not produce $\mathrm{CO}_{2}$ when burning. Currently most of the hydrogen used in the world comes from natural gas (by methane reforming) and its interest to de-carbonize is not obvious, except if $\mathrm{CO}_{2}$ released during the process is captured and sequestrated.

Since a couple of years, hydrogen started to be produced by water electrolyze using renewable electricity (when not used in the grid). This type of production, named Power to Gas, can contribute to global warming mitigation and could give the opportunity to store energy.

Storing hydrogen in existing underground gas storage facilities or dedicated storage facilities is possible for salt cavern storage facilities and currently under discussion for porous reservoirs. Research or pilot projects are launched to understand how hydrogen behaves in the subsurface (Marcogaz, 2016).

Occurrence of anomalous concentration of hydrogen gas in the continental subsurface is rare and quite a recent discovery. For example, first reporting in 1984 for Kansas-USA study case, up to 40\% (Angino et al., 1990) or in 1987 for Bourakebougou well in Mali with a content of $97 \%$ (Prinzhofer et al., 2018). The fact that $\mathrm{H}_{2}$ was not measured for routine analysis in the "western" petroleum industry is a lack to be filled when benchmarking V. Sokolov synthesis written in 1974. Measurements of hydrogen used to be more systematic in CIS and they demonstrate that concentration of hydrogen up to $25 \%$ is not so rare in natural gases accumulation. Also, set of data shows hydrogen saturation up to $90 \%$ for Japanese volcanic activity (Sokolov, 1974).

Some continental natural hydrogen seeps have been discovered (Larin et al., 2015; Prinzhofer and Deville, 2015, Prinzhofer et al., 2019) but we are far from understanding hydrogen sources, hydrogen migration and hydrogen behavior in the subsurface. (Nivin, 2016; Gregory et al., 2019). The interest for the topic was renewed recently and suffers from poor data sets. A source of natural hydrogen, if available in reasonable conditions, would provide decarbonized and perhaps renewable energy, if the origin is proved to be partially linked with deep crustal or magmatic reservoir source and then would take a great part in the energy transition.

It is the reason why any case study of natural hydrogen deposit is of high interest.

Vaux-en-Bugey gas condensate field, containing around $5 \%$ of hydrogen, is one of these case studies. As an upside, helium content was high in Vaux-en-Bugey. This valuable gas generation is also addressed.

The objective of this work is to test the different hypothesis of generation and migration of gases, focussed on hydrogen and helium, for the specific case of Vaux-en-Bugey field consistently with the specific geological setting. The evolution of hydrogen content in the field is addressed based on recent measurements.

The first experience of gas production in France may provide key understandings for natural hydrogen generation and storage.

\section{Vaux-en-Bugey gas field exploration- production history and geological context}

The geographical location of the field is presented in Figure 1 and Figure S3 for wells location.

\subsection{History of the exploration-production}

Vaux-en-Bugey gas field was discovered in 1906 when the Pagniez-Bregi well was drilled. The target of this exploration was to find salt or coal. A gas bearing horizon was found at 190.6 and $216 \mathrm{~m}$ below ground level and a blow-out happened. The well was roughly plugged and abandoned.

In 1917-1919, the "Syndicat d'Études et de Recherches du Bugey" drilled Torcieu well for coal, $2 \mathrm{~km}$ Nord-Est of the discovery well.

After the first World War, a company ("Société Civile de Recherche de Vaux") drilled a gas well (SCRV) in 1919 but it didn't provide a sufficient gas delivery rate. A mining licence (called Buisin from the name of the small river crossing the zone) was granted to SREP and the commercial production started in 1924.

A company ("Société de Recherche et d'Exploration Pétrolière", i.e. SREP) launched a drilling campaign of 5 wells (SREP1 to SREP5). All wells (except SREP1) found gas but the main production well of the field was SREP2. A blow out occurred during drilling releasing around 6 million $\mathrm{m}^{3}$ of gas in the atmosphere.

A gas pipeline was built to transport the gas to the nearby city of Ambérieu where it was used mainly for lighting. This discovery raised great expectations, to supply Lyon and a glass factory built in the neighbourhood. The connection to Lyon was never realized and the supply to the glass factory was temporary and not sufficient. (Charpy, 1990).

A process (based on active coal adsorption) to withdraw gasoline $(\mathrm{C} 5+)$ from the gas provided around $301 / 1000 \mathrm{~m}^{3}$ (Locherer, 1927).

A dedicated station was built to pressurize gas into mobile vessels to provide fuel gas for vehicles (see Fig. 1).

The production was very low after 1950 and was totally stopped after 1961.

\subsection{Geological context}

Vaux-en-Bugey gas field is located in the southern part of Jura mountains, outermost margin of western Alps, East of France (see Figs. 2 and 3).

At the end of nappes formation in the Alps (major phase is middle Miocene, around $15 \mathrm{Mybp}$ ), this banana-shaped mountain was compressed, folded and pushed toward the Northwest. The Mesozoic sediments (above the Triassic evaporitic facies) put under stress were thrust onto the OligoMiocene sediments of the Bresse graben (Pfiffner, 2014). The age of Vaux-en-Bugey thrust is $5 \mathrm{My} \mathrm{bp}$, ante Pliocene to ante Plaisancian, from 5.3 to 3.6 Mybp (Vincienne, 1932; Glangeaud, 1953). The gas accumulation is located within the thrusted sediments.

Transverse NW-SE strike sleep faults, as Pont d'Ain-Culoz deep fault (Philippe, 1994) gave the general shape of the chain. Vaux gas field is located along the southernmost NW-SE one, "Rhône fault". This fault is the border between folded Jura mountains and lower tabular "Ile Crémieu".

\subsubsection{Stratigraphic setting}

Synthetic lithostratigraphy for Vaux-en-Bugey and Torcieu area is presented in Figure 4. 


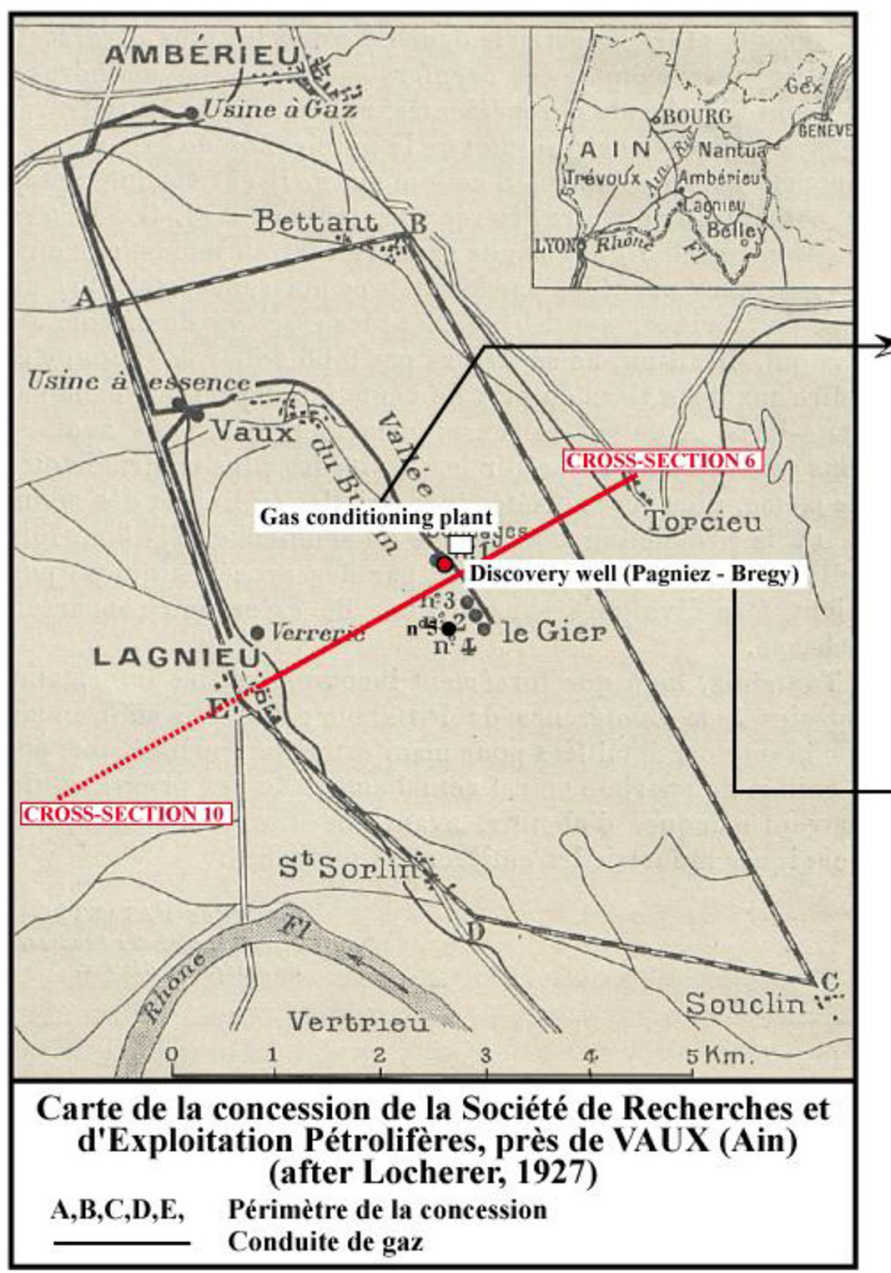

Fig. 1. Vaux-en-Bugey gas field location map.

As the field is located within a thrust, lithostratigraphy is uncertain, although 7 wells drilled, because of lacks or series overlaps. No logging tools were available at that times and only two wells get cores (SREP3 and SREP4).

At Vaux-en-Bugey location, the continental crust thickness is around $30 \mathrm{~km}$, so in-between thin one $(24 \mathrm{~km})$ for Massif Central-Forez and thick one (up to $58 \mathrm{~km}$ ) for Alpine domain (Grellet et al., 1993). There is no magmatic evidence recorded in the area. Top of the basement is dipping South-East from the West border of Jura chain toward Alps (Philippe, 1995). The same feature, is known for "Ile Crémieu" basement (Rocher et al., 2004).

The upper part of the basement, outcropping westward in Massif Central (uplifted during Hercynian and Cadomian orogeny) and eastward in Belledonne massif (uplifted during Alpine orogeny) and also South of Ile Crémieu at Chamagnieu, drilled in some few wells is a standard igneo-metamorphic type. The age of the basement is still uncertain: if main part is linked to the Hercynian orogeny (from Devonian to Permian), remains the possibility of neo-Proterozoic pieces, linked to the Cadomian orogeny (Chiron and Kerrien, 1979). Anyway, Vaux-en-Bugey is located $50 \mathrm{~km}$ South of internal crystalline nappes and ophiolitic structures of Hercynian orogeny (Grellet et al., 1993).

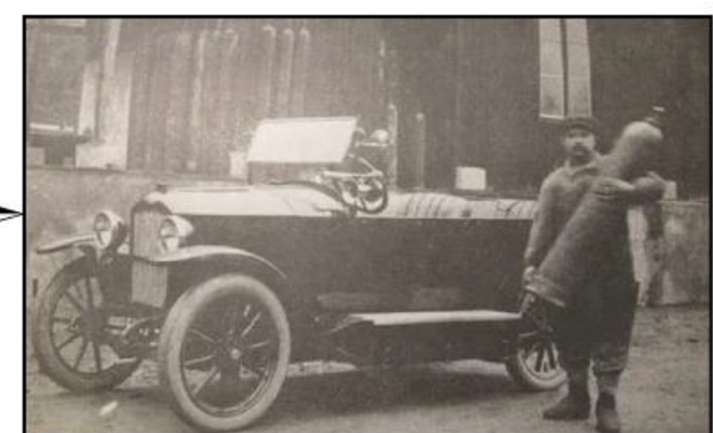

Gas conditioning plant. In 1924, the gas contains $5 \%$ of $\mathrm{H}_{2}$

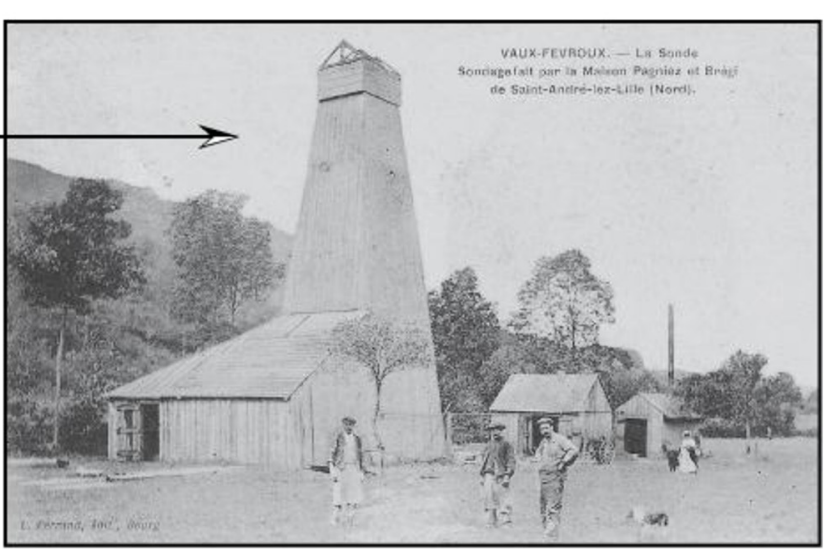

Discovery well (1904)

Paleozoic sediments are present along a SW-NE trend (Debrand-Passard et al., 1984), outcropping South in the exploited Saint-Étienne Basin with Stephanian-Autunian coal measures and bituminous shales but only explored in subsurface within Bas-Dauphiné Basin (Mariton, 1981). These formations get a prolongation North-eastward in Vaux-en-Bugey area, as seen in Torcieu and Chatillon wells. The presence of Permo-Carboniferous is attested in Vauxen-Bugey SREP4 well, by coring samples. At Torcieu well, the $1187 \mathrm{~m}$ drilled section below Triassic got $100 \mathrm{~m}$ of Permian shaly sandstones then Carboniferous black schist, psammites and millimetric coal laminations (Fig. S2).

Mesozoic sediments partly outcropping in the area have been detailed in the rich and exhaustive synthesis of the field, by Schoeffler (1941).

Lower Triassic Buntsandstein fluviatile sandstones, the main regional reservoir, is $48 \mathrm{~m}$ thick at Torcieu well and absent at Vaux-en-Bugey.

Middle Triassic Muschelkalk is $98 \mathrm{~m}$ thick in Torcieu well with marly and dolomitic or calcareous facies.

Upper Triassic Keuper (estimated thickness of $150 \mathrm{~m}$ ), consists of repetitive sections of iridescent marls, gypsum and dolomitic layers from lacustrine environment. 

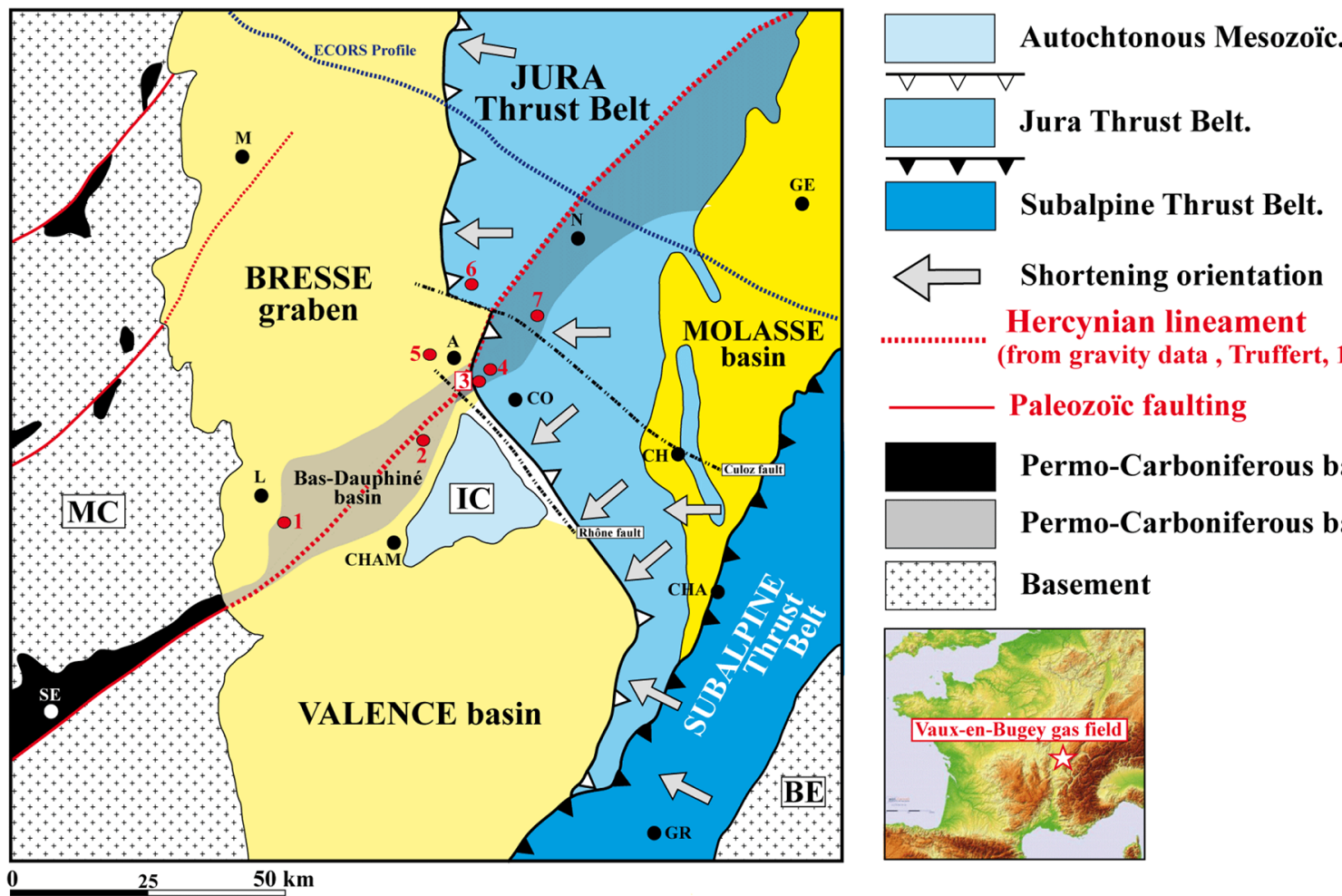

Hercynian lineament

(from gravity data , Truffert, 1990)

Paleozoïc faulting

Permo-Carboniferous basin (outcrops).

Permo-Carboniferous basin (subsurface).

Basement

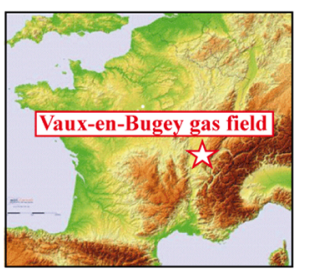

MC = Massif Central, $\mathbf{I C}=$ Île Crémieu, $\mathrm{BE}=$ Belledone massif.

$\mathrm{A}=$ Ambérieu, $\mathrm{CH}=$ Chautagne, $\mathrm{CHA}=$ Chambéry, $\mathrm{CHAM}=\mathrm{Chamagnieu}, \mathrm{CO}=\mathrm{Conand}, \mathrm{GE}=\mathrm{Genève}$, $\mathbf{G R}=$ Grenoble, $\mathbf{L}=$ Lyon, $\mathbf{M}=$ Macon, $\mathbf{N}=$ Nantua, $\mathbf{S E}=$ Saint-Etienne

Wells : 1 - St Priest, 2 - Blyes 101, 3 - Vaux-en-Bugey gas field, 4 - Torcieu, 5 - Cormoz, 6 - Bugey 101, 7 - Chatillon, Chaleyriat, La chandelière wells

Fig. 2. Regional structural map (from Debrand-Passard et al. (1984) and Philippe (1995), modified).
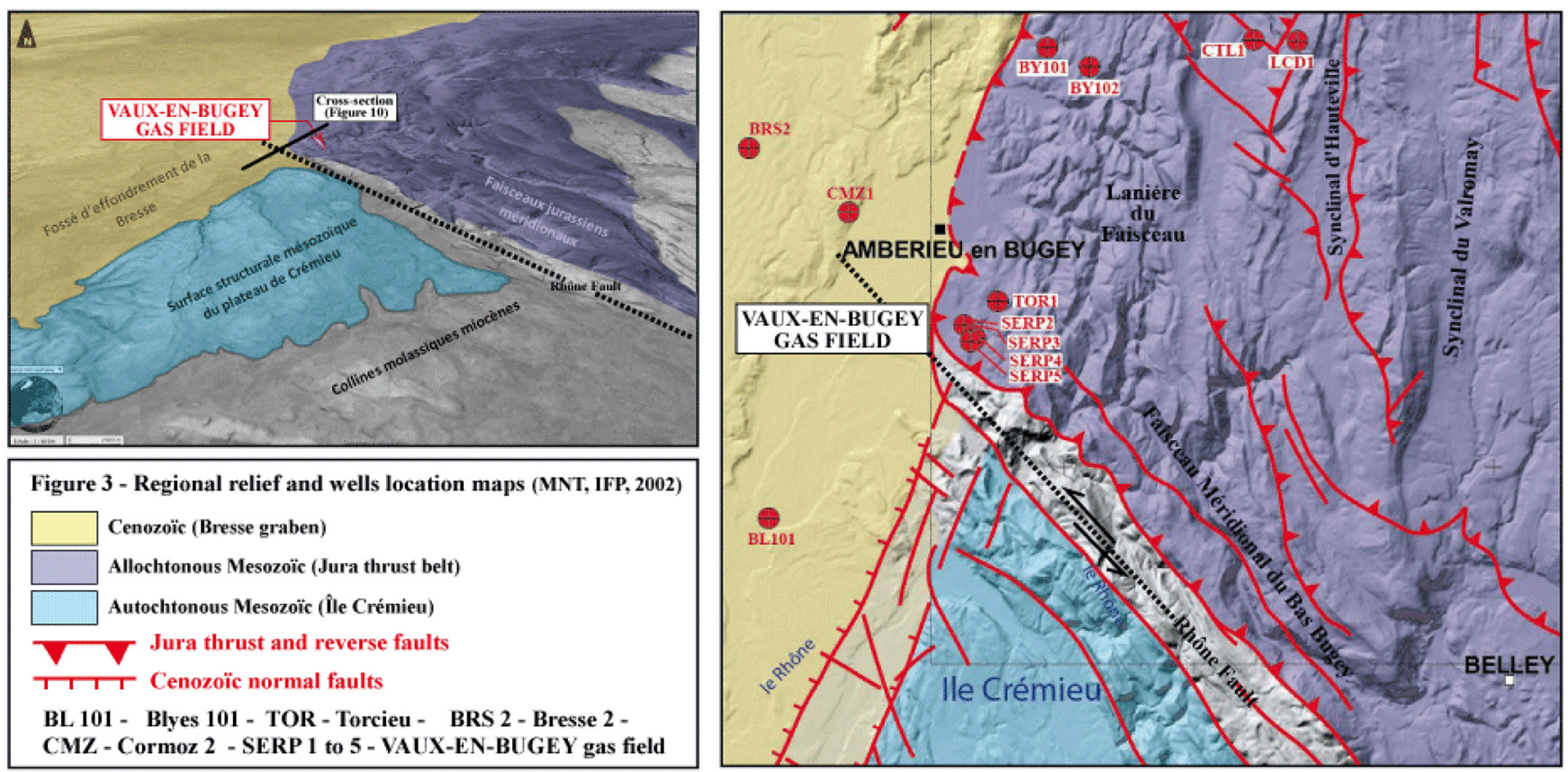

Fig. 3. Regional relief and wells location map (MNT, IFP, 2002). 


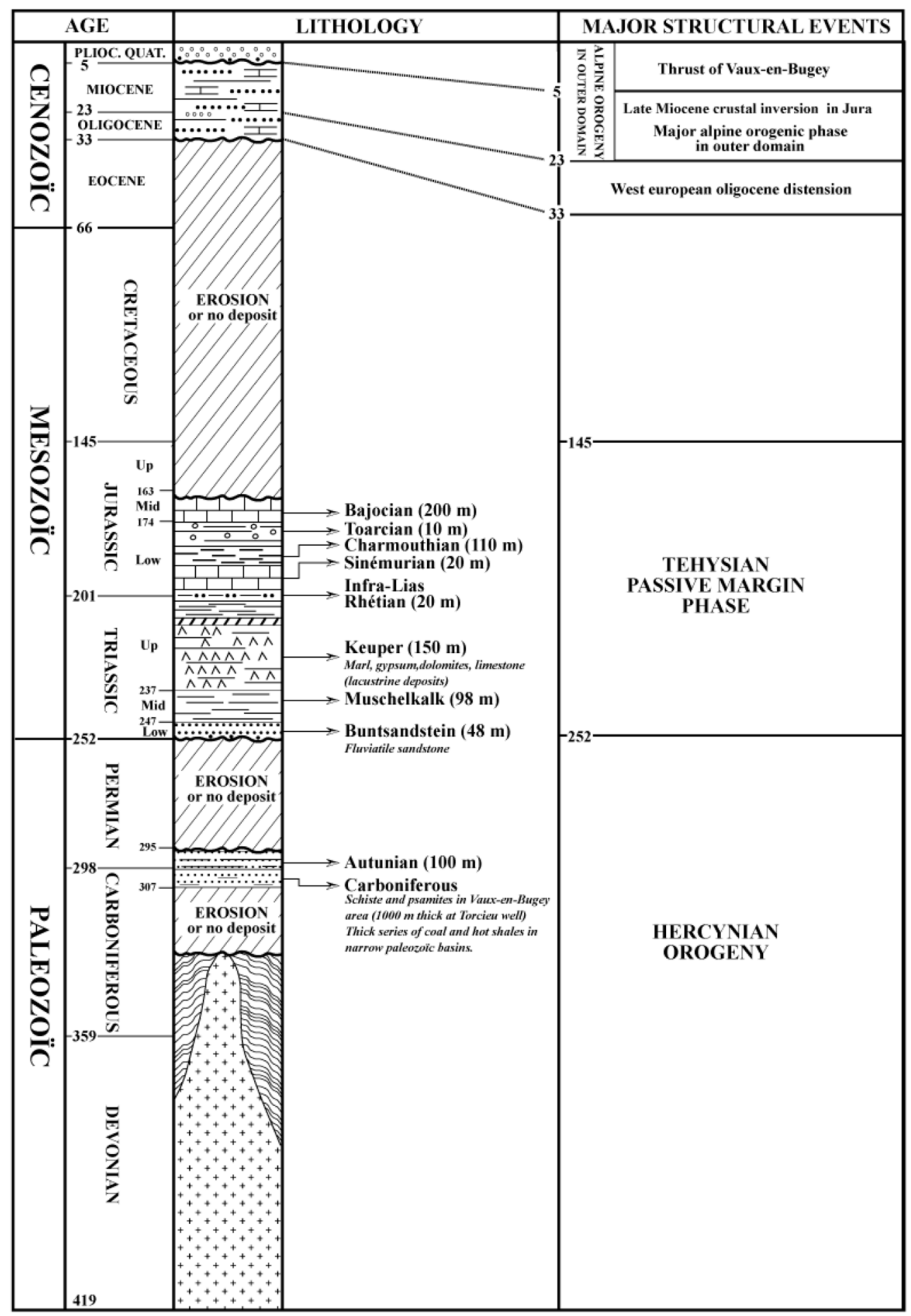

Fig. 4. Synthetic lithostratigraphy for Vaux-en-Bugey and Torcieu area. 
Challenging Schoeffler description, the authors suggest that the Keuper dolomitic gas reservoir is an equivalent of Lettenkhole formation and then located at the base of Keuper unit and not $5 \mathrm{~m}$ below the top. Because, first, the gas reservoir is always located 100 to $150 \mathrm{~m}$ below top Keuper and second because the Lettenkhole formation is regionally observed and not the upper Keuper equivalent "dolomie de Beaumont". This latter one disappears northward of Vaux as well as salty evaporitic facies (Dromart et al., 1994).

Liassic and Dogger formations (350 m thickness) outcropping partly in the Vaux Valley, develop marine shales and limestones with oolitic ferruginous grey shales $(3.5 \mathrm{~m})$ within Toarcian, just below the Bajocian and Bathonian main calcareous reliefs of the site. They have been exploited in Vaux-en-Bugey for iron mining.

Upper Jurassic and Cretaceous formations are eroded in the area.

Discordant Oligocene with green marly sandstones covers the Bajocian limestone in SREP5 well.

Miocene, $200 \mathrm{~m}$ drilled at SREP1, is made of molassic sediments including sandstone, marl and limestone.

\subsubsection{Trap formation, architecture and gas infilling}

Gas trap formation is the result of successive major structural events (Fig. 3):

- Hercynian orogeny: after the Cadomian, the area was deeply impacted and during late Paleozoic, in between mountain ranges was deposited the Stephanian-Autunian coal measures and bituminous shales, which have been affected by late Hercynian pulses with high crustal heat flows (as Saxonian volcanism). Vaux-en-Bugey gas field is located above this Permo-Carboniferous Basin-oriented SW-NE as proved by wells SREP4 (Vaux-en-Bugey), Torcieu and northward Chatillon. According to gravimetric data, an Hercynian lineament follow the Permo-carboniferous basins under the Jura thrust belt (Truffert et al., 1990; Philippe, 1995), see Figure 2;

- Mesozoic passive margin phase with opening of "LiguroPiemontais" ocean, did not disturb this feature;

- Oligocene extension phase created the deep Bresse Graben with a $2 \mathrm{~km}$ uplift of the basement on the East border, front of the Jura, as suggested by Ecors profile (Fig. 5). At a regional scale, there was a possible reactivation of old Hercynian features. As an illustration, the faults bordering the Bresse Graben have the same direction than the faults bordering the Bas-Dauphiné Permo-Carboniferous Basin (Fig. S1 cross-section a);

- Alpine orogeny: this late one got a paroxysmal phase at midMiocene, around $15 \mathrm{My}$ bp. As far as Jura is concerned, it is now admitted (Bergerat et al., 1990; Guellec et al., 1990; Truffert et al., 1990; Philippe, 1995; Madritsch et al., 2011; De La Taille, 2015) since the interpretation of the deep seismic Ecors profile, that a basement inversion phase during final Miocene is the origin of the Mesozoic thrusting sedimentary pile occurring post Miocene. This Miocene inversion is illustrated in Figure 5, along the Ecors profile;

- Nowadays, convergence between the Adriatic and European plates is still ongoing and significant seismicity is recorded in the area (De La Taille, 2015). The Ambérieu
(Chautagne) earthquake in 1822 (7.5 MSK intensity), (Fig. 6), or the more recent one in 2006 (3.7 magnitude) at Conand (Bureau Central Sismologique Français, 2006), (Fig. 7), are significative events. Jouanne et al. (1995) determine a $4 \mathrm{~mm} /$ year horizontal rate for the present-day displacement.

In this context, Vaux-en-Bugey gas field has a very specific structural location and situation.

The field is located at the intersection of two main fault trends affecting the basement (see Figs. 2 and 3). The geothermal gradient, as plotted by BRGM (BRGM, 2008), is high in the zone of junction of these two major structural trends, up to $45^{\circ} \mathrm{C} / \mathrm{km}$ (Fig. 8).

- the first one is NE-SW direction, bordering Bas-Dauphiné Basin along Ile Crémieu, reactivated during Oligocene extension from old Hercynian features;

- the second main direction of faulting is NW-SE, along Rhône River. It appears to be conjugated to the first one. Seismic line 88 Mex 03 when crossing this direction shows the creation of a narrow trough during Oligo-Miocene (Rocher et al., 2004) (Fig. S1 cross-section b). At present time and possibly since middle Miocene (15 My bp, main compressive phase in the Alps), a strike-slip faulting is occurring along the Rhône fault in between Jura and "Ile Crémieu" monoclinal unit (Philippe, 1995) (Fig. 3). On the surface, the Villebois fault has a $300 \mathrm{~m}$ offset (Kerrien and Monjuvent, 1990).

This location at the intersection of main structural accidents is favourable for deep gas degassing.

The field is also located above a top for lower Triassic fluviatile Buntsandstein reservoir, at a regional scale. This top is exactly located above the old Hercynian SW-NE remaining basin. This geometry is favourable to a good trapping of gases, at least since Oligocene, when the Bresse graben was created and the Jura basement was uplifted.

\subsubsection{A field in a thrusted ramp}

The cross-section, presented in Figure 9, N45 orientated, from Torcieu-SREP4 (Vaux-en-Bugey) and SREP5, to Lagnieu city, presents an updated interpretation which try to better illustrate the position and relation of the Mesozoic thrust over the Paleozoic and basement. Previous one is available from Schoeffler (1941) (Fig. 10).

Vaux-en-Bugey field is included within a thrusted ramp overlying the old Permo-Carboniferous layers. A mixt of fractured Mesozoic sediments pushed Oligo-Miocene molasse south-westward. This interpretation is consistent with the structural features described above: N130 Rhône fault, which cuts heavily all the Mesozoic series, just South of the field. The scheme is different on the East of Vaux-en-Bugey field ( $\mathrm{St}$ Sorlin, Villebois), where ramps overlap middle Jurassic series in front of the "Ile Crémieu" (Schoeffler, 1941). To the West, ramps overlap Miocene molasse (Philippe, 1995).

Three different slipping planes are depicted:

- the basal one is dipping SW and so illustrates a possible post Pliocene to present time inversion, as suggested by authors as Glangeaud (1953), Jouanne (1994) or De La Taille (2015). Consistently, Gros Foug relief is currently 

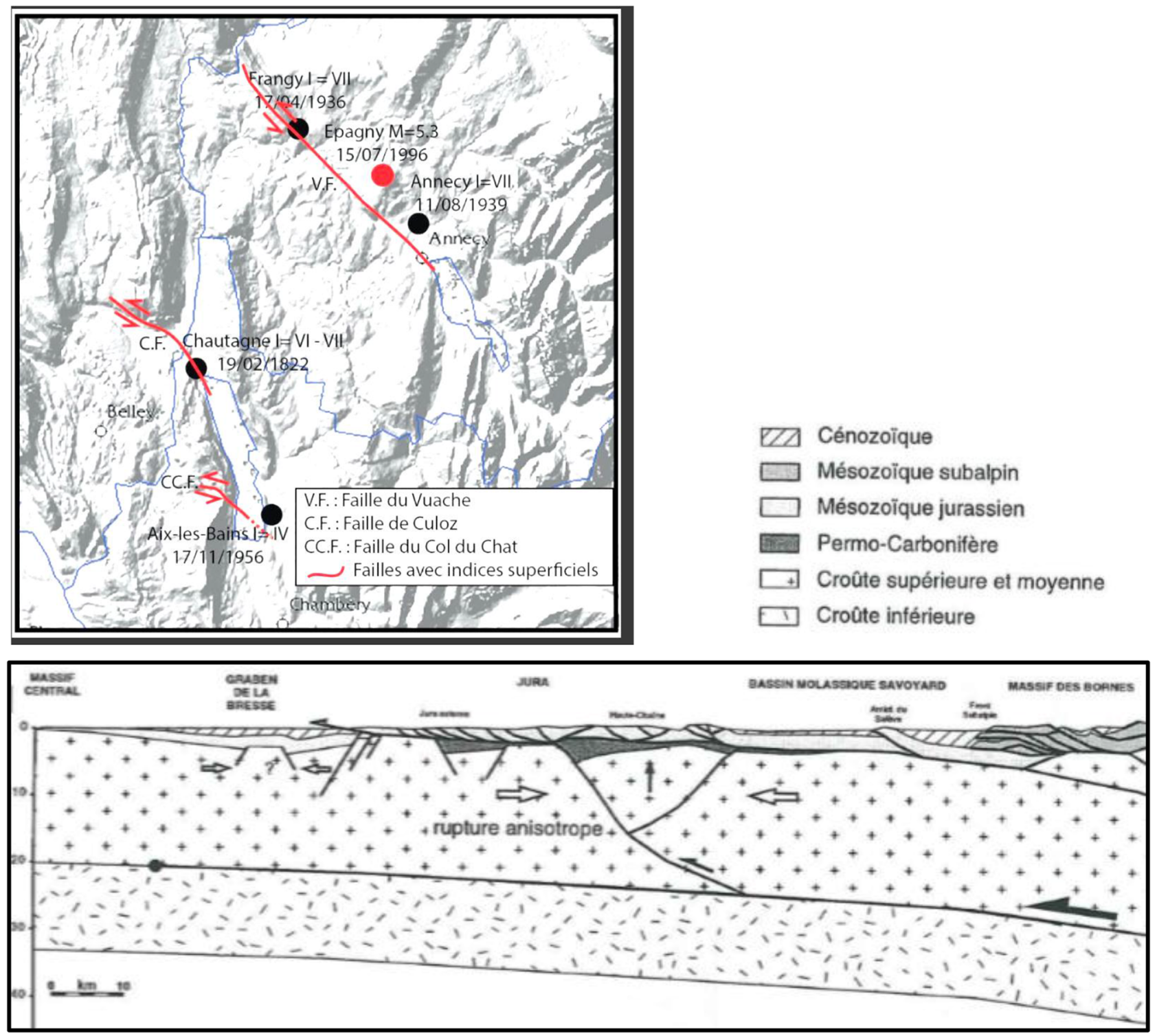

Fig. 5. Recent earthquake data (De La Taille C., 2015). Ecors profile cross-section (Philippe Y., 1995) - see location Figure 2.

uplifted. Jouanne et al. (1994), estimate a lateral displacement rate of $4 \mathrm{~mm} / \mathrm{y}$ for the basement, involving thrust which underlies the Jura. This feature is consistent with Torcieu and SREP4 wells data: the Muschelkalk (98 m thick) and Buntsandstein (48 $\mathrm{m}$ thick) drilled in Torcieu are missing in SREP4. So, the moving forward should be still active;

- the decollement located above shaly Muschelkalk, at the base of the evaporitic and lagunal facies of Keuper (Gypsum, shale and dolomite) generates a second slipping plane, base of a unit including Liassic pieces as drilled $80 \mathrm{~m}$ along in SREP4 well, $10 \mathrm{~m}$ in SREP5 and $0.4 \mathrm{~m}$ in Torcieu well with oolothic ferruginous oolithes;

- a third slipping plane, flanking the Liassic pieces, represents the base of a Keuper unit including removed pieces of dolomitic Lettenkhole reservoir near the base. It delineates with second, a liassic decametric thick section, highly perturbed by frictions and able to establish a vertical and transversal drain to the upward reservoir. This feature is interpreted here as part of a reverse anticline flank, as observed by drilling in S1, 2 and 3 wells (Keuper at surface, then Lias and Dogger at TD) $4 \mathrm{~km}$ Southeast of the field (Schoeffler, 1941).

Dogger limestone in front of the thrust (at TD for SREP5 well), above the basal slipping plane, is supposed to be part of the front brechia (fractured zone located under the thrust), rest of the overturned anticline.

The structure shape of the top of the field, based on the first gas occurrence depths on the different wells of the field (see Tab. 1) looks like an anticlinal with a top not far from SREP3 and a possible closure up to $60 \mathrm{~m}$. But the effective closure is $10-15 \mathrm{~m}$ for base Sinemurian limestone ("calcaire à Gryphées") $120 \mathrm{~m}$ above the reservoir.

Well SREP1, is located in another lowered compartment and did not find gas. 


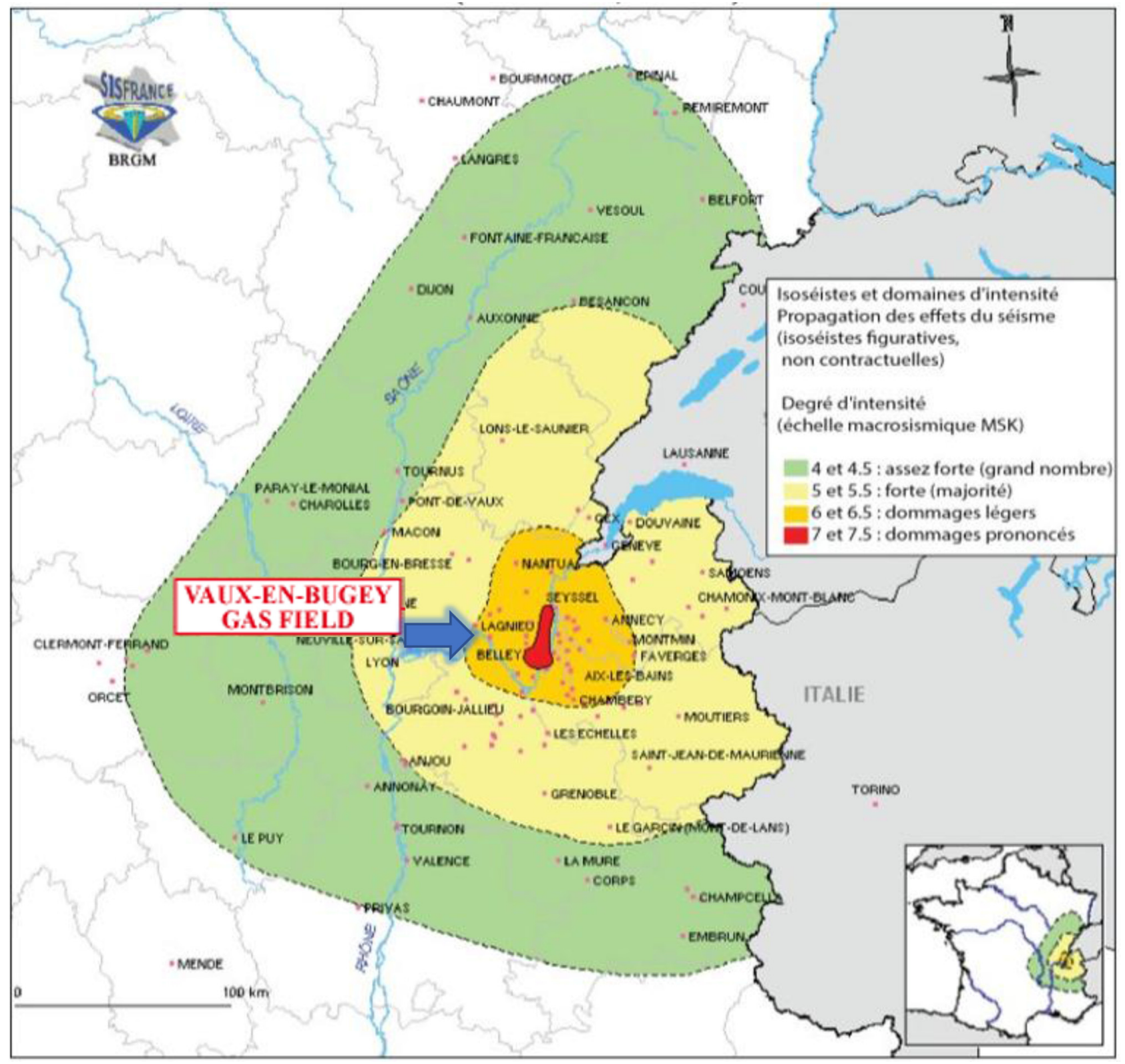

Fig. 6. Chautagne seismic event (1822). MSK intensity VII-VIII, magnitude (5,5-6). BCSF source.

The gas reservoir corresponds to Keuper dolomitic limestone (one or two layers) of few meters and even less. These horizons are interlayered with marls or shales and gypsum. This situation may lead to over-pressured reservoirs. This is the case for SREP2 at $222 \mathrm{~m}$ below ground level and perhaps for Pagniez-Bregi well. (see after).

\subsubsection{Gas infilling}

Gases have been probably trapped in a two steps mechanism (Fig. 11).

The initial area of gas trapping (trap 1) should be located along the marge of the Bresse Basin or northward, from Permo-Carboniferous Basin or deep faults. From post Oligocene uplift, the nearby Triassic Buntsandstein reservoir
(48 $\mathrm{m}$ thickness at Torcieu well) in preserved faulted tilted blocks, could be charged.

During late Miocene basement inversion or post Pliocene thrusting till present, faults are reactivated and a secondary migration to Keuper dolomitic formation was possible (trap 2).

To define when this last migration occurred, previous or post thrusting, is debatable and will be revisited in chapter 3.2 with pressure data from field production. Nevertheless, the described architecture of the thrust, fractured, with possible migration pathways vertically and laterally, together with oil and gas shows within the base of the decollement (Fig. 9) argue for a recent infilling.

An alternative scenario is to consider that the gas accumulation is the remaining of an older degassing taking place some $10 \mathrm{~km}$ Northeast. 


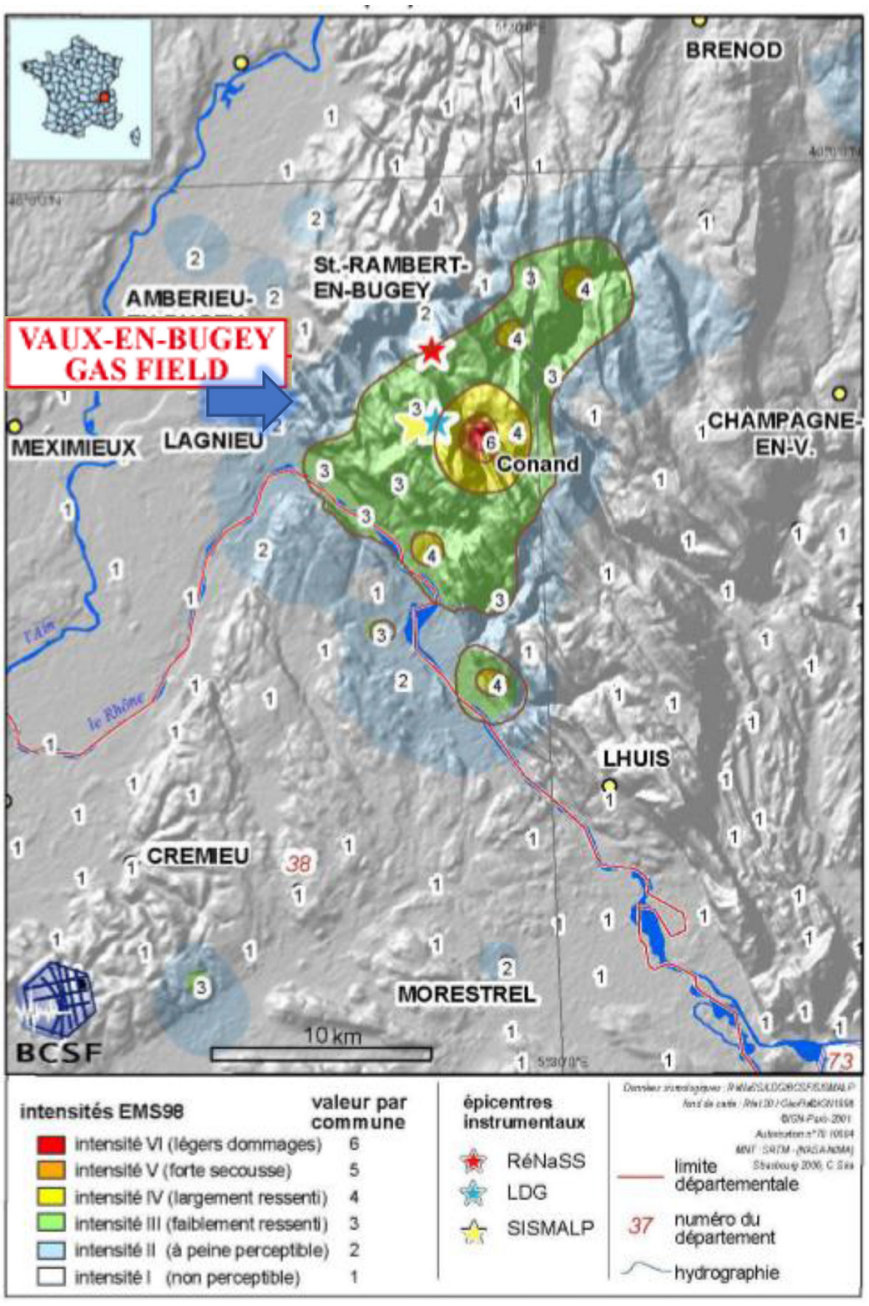

Fig. 7. Conand seismic event (2006). Magnitude (3.7), epicenter depth $=1-2 \mathrm{~km}$. BCSF source.

\section{Vaux-en-Bugey gas contain}

\subsection{Volume produced}

SREP3 is at the top of the gas zone but the poor thickness of the reservoir $(0-10 \mathrm{~m})$ in this well, could explain the fact that the gas production of this well was very poor.

Even with some uncertainty, authors give information on the depletion of the field (Schoeffler, 1941; Bonte, 1948; Charpy, 1990). The main uncertainties are the volume of gas released during the discovery well (Pagniez-Bregi) blow-out and the production during the last period (1956-1961). Figure 12 presents a reconstructed production history, based on the hypothesis of a gas release of 2.6 million $\mathrm{m}^{3}$ ( 10 days of blowout) and a zero production between 1956 and 1961. The blow-out on SREP2 is estimated to 6 million $\mathrm{m}^{3}$ by Bonte (1948).

\subsection{Pressure depletion}

Pressure values are even more uncertain than volumes. They are measured in $\mathrm{kgf} / \mathrm{cm}^{2}$ at the well head during production and the dates corresponding to the different measures are not precise. Some values correspond to well SREP2 and others to well SREP5 or SREP3 (used to measure pressure). Some values correspond to the pressure in the upper layer (SREP5) or the deeper on or an average of the two values.

Considering the low level of pressure, $\mathrm{z}$ factor is near 1 . It is the reason why the Figure 13 is a P/volume cross plot.

Two values are particularly interesting:

- the pressure on SREP2 before and after blow-out (i.e. production of 6 million $\mathrm{m}^{3}$ ). The gas venue started at $221 \mathrm{~m}$ with a well full of water (Schoeffler, 1941) That means that the reservoir pressure was 22 bars or more. We choose this minimum value to report in on the graph;

- the value of $15 \mathrm{kf} / \mathrm{cm}^{2}$ is given after stabilization and pressure build-up (Schoeffler, 1941).

This cross plot suggests three important results:

- first, due to all uncertainties, the curve is not a real right but a clear linear trend could be drawn. That means that there is no water driving effect, that no pressure support is provided by an aquifer. It is consistent with the description of the reservoir: dispersed dolomitic beds with vacuoles plugged by marls and gypsum. A measure of pressure on SREP5 in 2018, performed by the authors, gave a value of 1 bar (absolute) at the well head. This very low value, almost 6 decades after the end of production, if representative, would confirm that the reservoir is isolated;

- secondly, to fit with the trend, specially the two measures of pressure before and after SREP2 blow-out, the discovery pressure (which we do not know) should be around 10 bars over the hydrostatic pressure. This is consistent with an isolated and uplifted reservoir and could explain the violence of the two blow-outs. The estimated initial pressure, 10 bars over the hydrostatic, could be explained by a $100 \mathrm{~m}$ structural uplift during the thrust transport;

- thirdly, the total volume of gas initially in place is around 22 million $^{3}$ (the approximative crossing point between the depletion right and the axis of gas produced) and the recovery factor is very high: around 20.73 (million $^{3}$ of gas production $) / 22$ (million $\mathrm{m}^{3}$ of gas initially in place $)=94 \%$.

\subsection{Gas quality}

Gas quality was measured several times on the well Pagniez Bregi and on production well SREP2 (Bregi, 1909; Schoeffler, 1941). Table 2 presents these data and recent data which will be discussed hereafter.

These analyses show the contents of alkanes $\left(\mathrm{C}_{1}\right.$ to $\mathrm{C}_{4}$ : around $90 \%$ ), nitrogen $\left(\mathrm{N}_{2}\right.$ : around $5 \%$ ), of carbon dioxide $\left(\mathrm{CO}_{2}: 0.5\right.$ to $\left.5 \%\right)$, hydrogen $\left(\mathrm{H}_{2}: 3.5\right.$ to $\left.5 \%\right)$ and noble gases specially helium with a content of $0.096 \%$ (Lepape, 1958).

The analysis mentioned by Locherer (1927) is different: it mentions a zero-hydrogen content, which is not consistent with the Pagniez Bregi analysis (1909) and the Schoeffler one (1941).

To try to check $\mathrm{H}_{2}$ content, a calculation on calorific value was done. A global calorific value of $9500 \mathrm{kCal} / \mathrm{m}^{3}$ is mentioned by Locherer (1927). This value seems globally consistent either to Locherer analysis without $\mathrm{C}_{5}+$ gasoline or with Schoeffler analysis taking into account $\mathrm{C}_{5}+$ calorific value. This approach cannot allow to conclude clearly. 


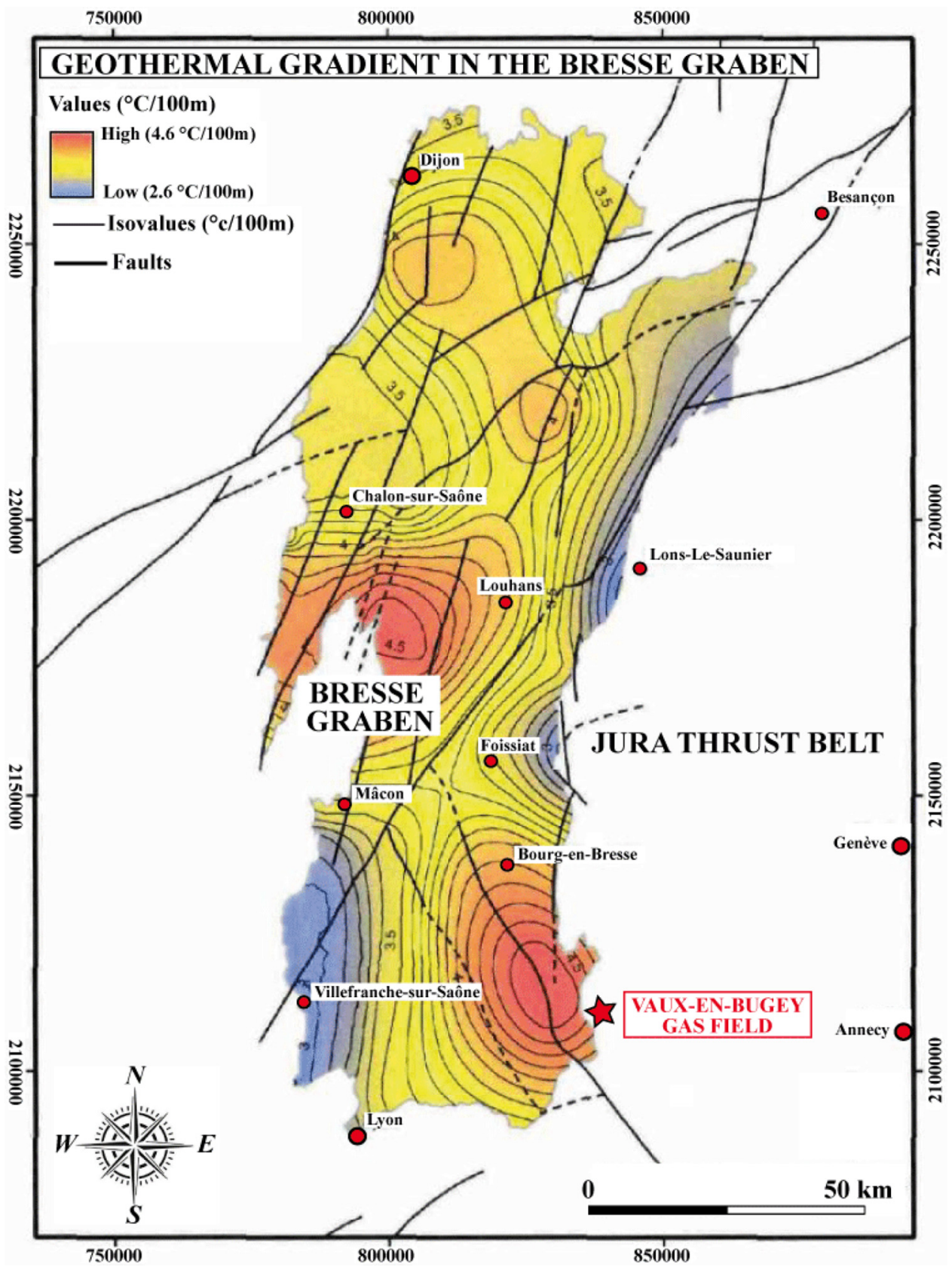

Fig. 8. Geothermal gradient in Bresse Basin (BRGM, 2008).

Nevertheless, the authors do not trust Locherer data a lot, because it is different than the two other ones and because Locherer does not mention the origin of his data.

Based on a total volume of gas initially in place of 22 million $\mathrm{m}^{3}$ and an initial content of around $5 \%$ of hydrogen, Vaux-en-Bugey gas field had contained 1.1 million $\mathrm{m}^{3}$ of hydrogen.

No $\mathrm{H}_{2} \mathrm{~S}$ content values are available during historical production period but it was reported that the gas smelled heavily during production period which suggests a significant content of $\mathrm{H}_{2} \mathrm{~S}$ (Bonte, 1948). Moreover, sulphur found in the cracks of the reservoir cores was noticed (Schoeffler, 1941). This sulphur probably crystallized from $\mathrm{H}_{2} \mathrm{~S}$ in contact with oxygen, the oxygen being supplied by mud or air during coring and drilling.

\section{Discussion on gases origin}

A schematic charge processes is presented in Figure 11 for gases accumulation. The origin of the different gases of Vauxen-Bugey field needs to be discussed since the different components have not necessarily the same origin. A special focus is done on hydrogen and helium.

\subsection{Methane and alkanes}

Still exists a debate concerning the origin of natural hydrocarbon gases as methane and light ones till pentane (Etiope and Schoell, 2014). Most of the time, generation of 

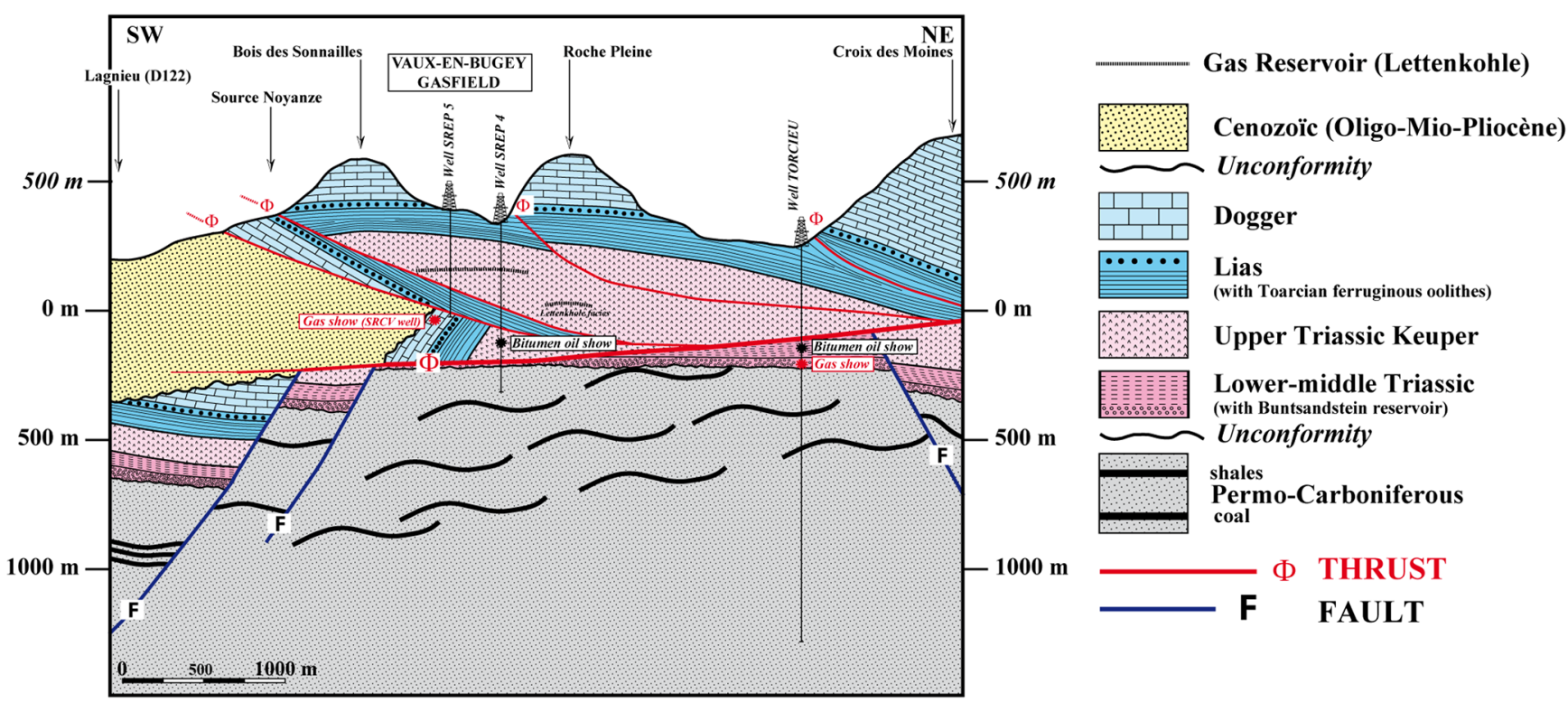

Fig. 9. Schematic interpretative cross-section.

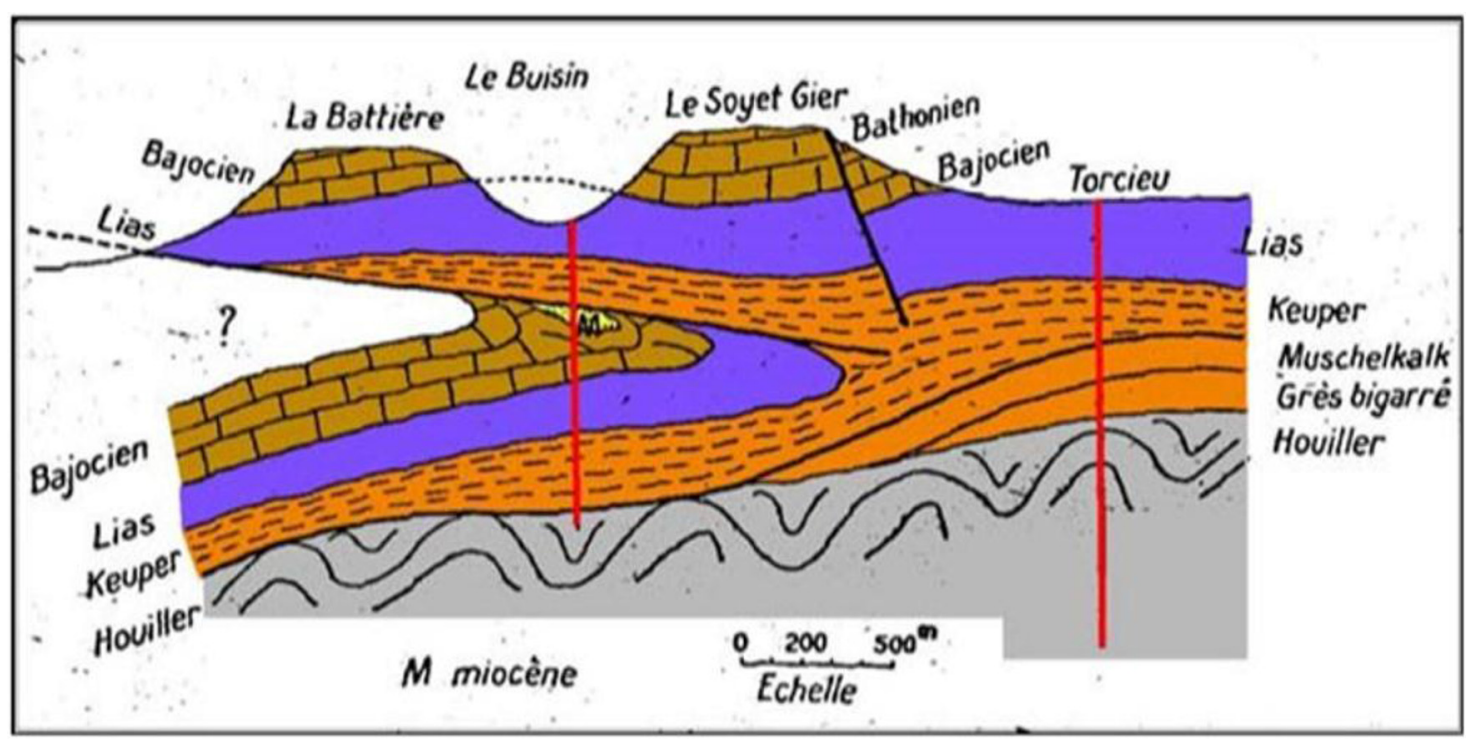

Fig. 10. Schematic interpretative cross-section (Schoeffler, 1941).

such gases could be explained by the microbian or thermal evolution of organic matter concentrated in sedimentary rocks. This process, named biotic seems well adapted to Vaux-enBugey gas field.

Carboniferous and Permian sources rocks are present to the South in the Bas-Dauphiné Basin and also to the North. In Charmont well (NE of Vaux) carboniferous coals are $52 \mathrm{~m}$ thick and for Chatelblanc well, maturity modelling suggests onset gas generation during early Cretaceous for Autunian source (Pullan and Berry, 2019).

At present time, recorded Tmax (the range is 435-470 in the oil window) in the Bas-Dauphiné Basin and basin modelling for Stephanian coals, over $1000 \mathrm{~m}$ deep (Guellec et al., 1990), explain easily a methane generation. The quality of these sources is high with petroleum potential of 20 to
$180 \mathrm{kgHC} / \mathrm{t}$ for Stephanian coals, 5 to $500 \mathrm{kgHC} / \mathrm{t}$ for Stephanian bituminous shales and 5 to $120 \mathrm{kgHC} / \mathrm{t}$ for Autunian bituminous shales. In Chassieu well, representative of the basin, total thickness of source rocks is around $30 \mathrm{~m}$ (Blanc et al., 1991). Methane probably comes from Stephanian coal more deeply buried and light hydrocarbons from Permian (Autunian) shales. Early generation of oil and methane from Permian-Autunian bituminous shales and from Stephanian coal measures and bituminous shales, started at the end of Cretaceous at least (Blanc et al., 1991). After the Oligocene pre-rift phase, part of the source rocks buried deeper got more mature in the Bresse Basin and also within the Jura chain, uplift of coals during Miocene alpine phase could produce methane by decompression.

It has to be mentioned that the Autunian hot shale formation occurrence is far from Vaux location $(60 \mathrm{~km})$. This formation is 
Table 1. Vaux-en-Bugey markers table.

\begin{tabular}{|c|c|c|c|c|c|c|c|c|}
\hline Well & Years & $\begin{array}{l}\text { Ground } \\
\text { level } \\
\mathrm{m} / \mathrm{sl}\end{array}$ & $\begin{array}{l}\text { Total } \\
\text { depth } \mathrm{m} / \mathrm{gl}\end{array}$ & $\begin{array}{l}\text { Top trias } \\
\mathrm{m} / \mathrm{sl}\end{array}$ & $\begin{array}{l}\text { Top } \\
\text { Buntsandstein } \\
\mathrm{m} / \mathrm{sl}\end{array}$ & $\begin{array}{l}\text { Top Permo- } \\
\text { Carboniferous } \\
\mathrm{m} / \mathrm{sl}\end{array}$ & $\begin{array}{l}\text { Gas occurrence }(\mathrm{m} / \mathrm{gl}) \\
\text { and production } \mathrm{m}^{3} / \mathrm{d}\end{array}$ & $\begin{array}{l}\text { First gas } \\
\text { occurrence } \\
\mathrm{m} / \mathrm{sl}\end{array}$ \\
\hline SREP2 & 1921 & 340 & 223 & 261.0 & NR & NR & $\begin{array}{l}-217 \text { with } 10000 \mathrm{~m}^{3} / \mathrm{d} \text { and } \\
-222 \text { with } 110000 \mathrm{~m}^{3} / \mathrm{d}\end{array}$ & 123 \\
\hline SREP4 & 1923 & 342 & 662 & 266.0 & NR & -242 & $\begin{array}{l}-241 \text { with } 1500 \mathrm{~m}^{3} / \mathrm{d} \text { and } \\
-280 \text { with very weak gas }\end{array}$ & 101 \\
\hline SREP5 & 1924 & 390 & 354 & 279.0 & NR & NR & -270 with $900 \mathrm{~m}^{3} / \mathrm{d}$ & 120 \\
\hline
\end{tabular}

(Source: from Schoeffler, 1941).

Nota: $g l=$ ground level; $\mathrm{sl}=$ sea level; positive depth figures means above the reference; NR= not reached.

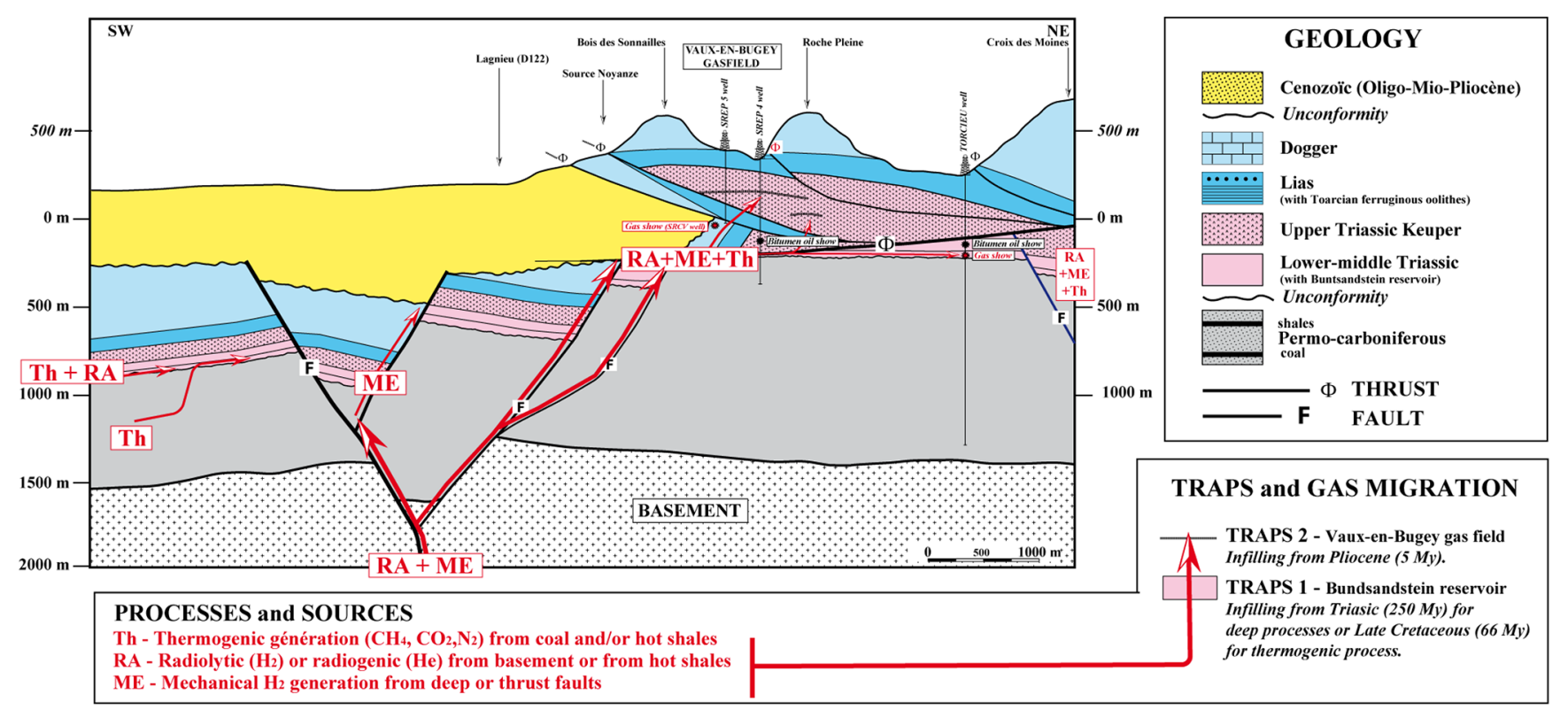

Fig. 11. Schematic charge processes (Vaux-en-Bugey gas field).

dipping toward the North-East, outcropping in Givors, and reach $1000 \mathrm{~m}$ deep at St Priest (20 km East to Givors) according to Mariton (1981) and Gudefin (1980). This horizon is unknown northward of the basin, only mentioned in Blyes 101 well $(-975 \mathrm{~m} / \mathrm{sl}$ for top Permo-Carboniferous) and missing in Cormoz well (East of Ambérieu). This Paleozoic formation is $500 \mathrm{~m}$ deep in Vaux SREP4 and Torcieu wells but without the hot shales and coal facies as in Torcieu well $(1157 \mathrm{~m}$ drilled Paleozoic section for Torcieu well. See Tab. 1).
Evidence of thermogenic methane system could be validated for Blyes 101 well, with a gas show (composition not available) during drilling, in Buntsandstein reservoir: this well is located on the South-East border of Bas-Dauphiné Basin (see Figs. 2 and 3).

A biogenic origin for methane is not relevant for Vaux-enBugey case study, as gas composition shows upper alkanes concentration up to $8 \%$ (refer Tab. 2). Assessed biogenic accumulations get almost pure $\mathrm{CH}_{4}$. 


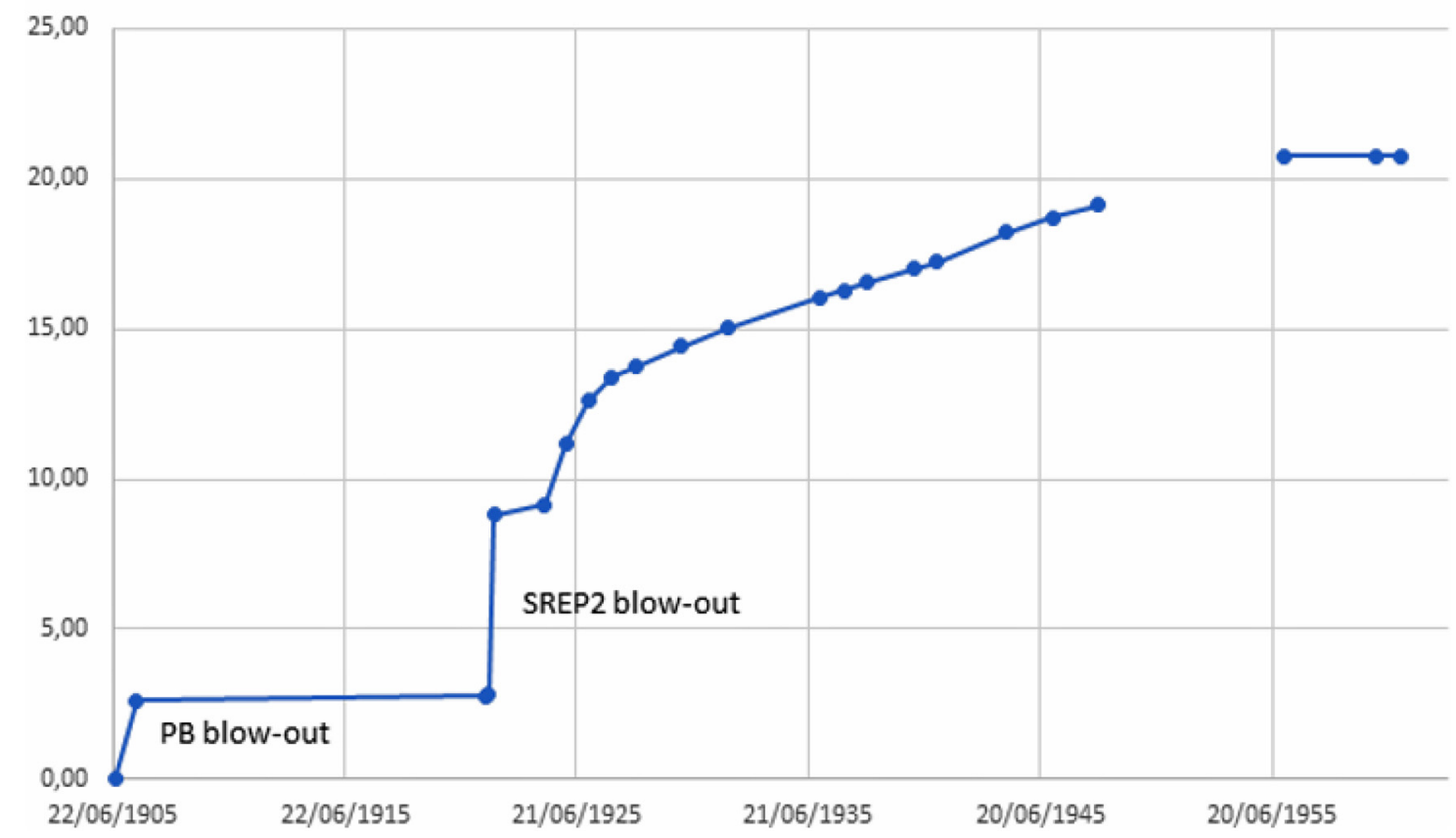

Fig. 12. Production history of Vaux-en-Bugey gas field.

\section{pressure ( bara-datum $157 \mathrm{~m} / \mathrm{sl}$ ) versus gas production (millions m3)}

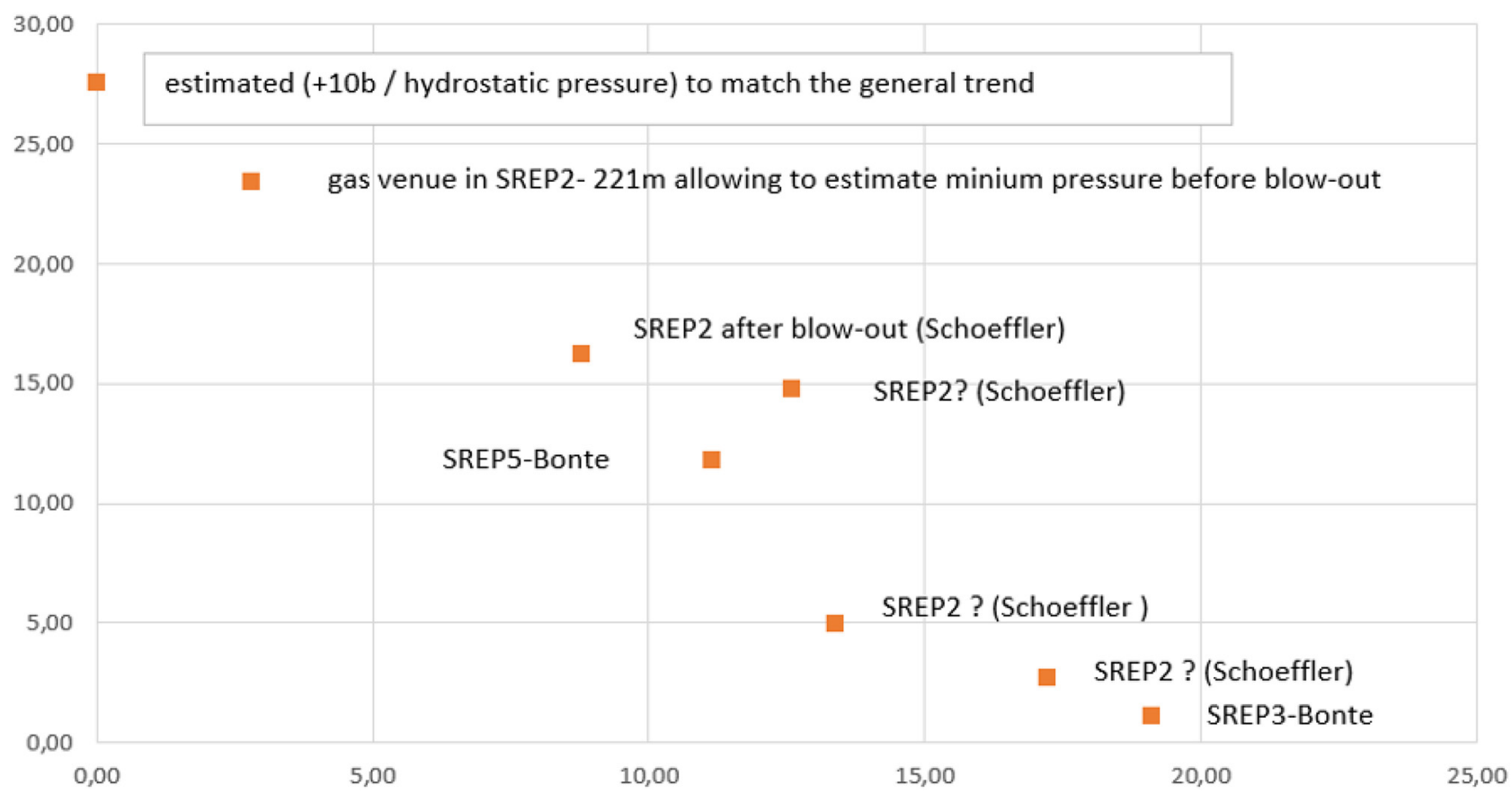

Fig. 13. Pressure versus production cross-plot for Vaux-en-Bugey gas field. 
Table 2. Vaux-en-Bugey gas quality data.

\begin{tabular}{|c|c|c|c|c|c|c|c|c|c|c|c|c|c|c|}
\hline $\begin{array}{l}\text { Date of the } \\
\text { measure }\end{array}$ & Well & $\begin{array}{l}\mathrm{CH}_{4} \\
(\%)\end{array}$ & $\begin{array}{l}\mathrm{H}_{2} \\
(\%)\end{array}$ & $\begin{array}{l}\mathrm{C}_{2} \mathrm{H}_{4} \\
(\%)\end{array}$ & $\begin{array}{l}\mathrm{C}_{3} \mathrm{H}_{6} \\
(\%)\end{array}$ & $\begin{array}{l}\mathrm{C}_{4} \mathrm{H}_{10} \\
(\%)\end{array}$ & $\begin{array}{l}\text { Combustible } \\
\text { gases }\end{array}$ & $\begin{array}{l}\mathrm{CO}_{2} \\
(\%)\end{array}$ & $\mathrm{N}_{2}(\%)$ & $\begin{array}{l}\text { Ar, Kr, } \\
\text { Xe (\%) }\end{array}$ & $\begin{array}{l}\mathrm{He}, \\
\mathrm{Ne}(\%)\end{array}$ & $\begin{array}{l}\mathrm{H}_{2} \mathrm{~S} \\
(\mathrm{ppm})\end{array}$ & $\begin{array}{l}\text { Reference of } \\
\text { the analysis }\end{array}$ & Comment \\
\hline 1926 & SREP2 & 79.27 & 5.24 & 4.91 & 3.17 & 0.14 & 92.73 & 2.36 & 4.91 & & & NA & $\begin{array}{l}\text { Lebeau mentionned } \\
\text { by Schoeffler (1941) }\end{array}$ & \\
\hline 1933 & SREP2 & NA & NA & NA & NA & NA & 89.28 & 5.2 & 5.41 & 0.016 & 0.096 & NA & $\begin{array}{l}\text { M. Lepape mentionned } \\
\text { by Schoeffler (1941) }\end{array}$ & \\
\hline 09 -avr-18 & SREP5 & NA & 0.52 & NA & NA & NA & & 4.9 & NA & NA & NA & 136 & Deronzier & \\
\hline
\end{tabular}

Measurements are in \% or ppm of volume.

$\mathrm{NA}=$ non available.

It must be mentioned that $\mathrm{CH}_{4}$ could be produced by bacteria or chemical reaction (Sabatier reaction) from $\mathrm{CO}_{2}$ and $\mathrm{H}_{2}$. This mechanism is discussed in 4.2 and assessed as poorly probable during the depletion phase of the field.

As a conclusion: alkanes thermogenesis should be efficient for the field.

\subsection{Carbon dioxide}

$\mathrm{CO}_{2}$ in the subsurface could have different origins (Jeandel, 2008).

Some of them are inorganic:

- mantle or magma degassing as in Montmirail (Drôme,

France) $\mathrm{CO}_{2}$ field (Jeandel, 2008; Crossey et al., 2009);

- metamorphism of carbonates;

- dissolution of carbonates.

Some other processes are organic: kerogen maturation, metamorphism of coal, biodegradation of oil and gas.

Dioxide carbon saturation is around 5\% in Vaux gas. In the context of Vaux-en-Bugey, $\mathrm{CO}_{2}$ presence could be explained either by the organic maturation process or by mantellic origin and migration trough deep faults.

\subsection{Nitrogen}

Nitrogen in the subsurface could have different origins:

- atmospheric origin though subsurface water;

- organic material maturation specially coal, nitrogen atoms being provided by organic molecules as amino-acids. This gas is generated at higher temperature than methane (Littke et al., 1995);

- mantle or magma degassing (Ballentine and Lollar, 2002).

The atmospheric origin is not possible for Vaux-en-Bugey because its reservoir is tightly closed with no water flowing. The two others hypothesis are realistic.

\subsection{Helium}

This so rare element $(5.23 \mathrm{ppm}$ in the air $-960 \mathrm{ppm}$ in Vaux-en-Bugey gas), seems particularly well represented in Jura. Not only in Vaux gas field $(0.096 \%$ volume) but also in the Grozon gas well located Northward (in Lons-le-Saulnier area) with up to $1.34 \%$ volume (Ricour, 1956). As a comparison, remind that in the large Panhandle helium field (US-Texas) content varies within the field, from 1.3 to $0.1 \%$ (Gage and Driskill, 2003).

As helium is generated from radioactive decay of Uranium, Thorium and Potassium in mineral grains, the candidates as a source are old formations to allow a long radioactive process.

The Permian hot shales (270 My bp), previously cited, drilled in the "Bas Dauphiné" Basin, East of Lyon is a good candidate. Around 60 wells have been drilled in the area: they delineate a SW-NE oriented basin with middle Stephanian coaly formation at the base and just above an Autunian bituminous shale formation. Bed thickness of bituminous shale could reach $10 \mathrm{~m}$ and total thickness of the formation is more than $200 \mathrm{~m}$ by places.

As helium is solved preferably in gas than in water (Brown, 2010; Byrne et al., 2018), helium is transferred first from solid grains into pore water and then flushed by gaseous methane migration. Autunian formation complies with this scheme: there are beds of white coarse sandstone ("gore") at the base of the formation and in between bituminous shale beds. Moreover, as old, stagnant water collects more helium than young, hydrodynamic water, the "Bas Dauphiné" Basin, almost completely buried, may be relevant.

The helium may also come from the basement containing radioactive minerals and migrating by faults. This origin is realistic according to Vaux structural situation, described above: limited sedimentary cover (around $1500 \mathrm{~m}$ ) and deep faults to allow migration.

The helium, if produced by radioactive decay of very old minerals, either of the basement or hot shales, has been first stored in subsurface water then flushed by the natural gas phase. 


\subsection{Hydrogen}

\subsubsection{Different mechanisms of $\mathrm{H}_{2}$ theoretically available}

Present theories for $\mathrm{H}_{2}$ generation in the subsurface, are still in an infancy.

The following processes have been identified or proved in situ:

- serpentinization of ophiolite $\left(\mathrm{Fe}^{2+}\right.$ hydro-oxidation of olivine) (Deville et al., 2010; Malvoisin, 2013; Etiope and Schoell, 2014);

- radiolysis of water due to the presence of radioactive minerals (Lin et al., 2005);

- reaction of water with ${ }^{40} \mathrm{Ca}$ (produced by radioactive decay of ${ }^{40} \mathrm{~K}$ ) (Gregory et al., 2019);

- mechano-radical generation or cataclasis due to faulting (Hirose et al., 2011).

Experimental studies support that frictional mechanism liberates $\mathrm{H}_{2}$ from a range of silicate and non-silicate rocks, associated with water, and even dry basalt (using crystallographic water);

$2(=\mathrm{Si})+2 \mathrm{H}_{2} \mathrm{O}=>2(=\mathrm{SiOH})+\mathrm{H}_{2}$

Numerous field studies give a clear association between earthquake activity and high fluxes of hydrogen (also Radon and $\mathrm{CO}_{2}$ ). In Japan, Sugisaki et al. (1983) records concentrations up to $5000 \mathrm{ppm}(0.5 \%)$ within fault gouges of Nagoya District. For historic earthquakes, he plots several thousand ppm (several percent volume) for all historically active faults related to the earthquake. Lower values $(<200 \mathrm{ppm})$ are recorded within faults where the associated earthquake is unknown, classified as "prehistorical active fault". In China, Wang et al. (2018), precise that China began to observe the dissolved hydrogen in the 1970s: A scientific deep drilling exploration project has shown high value of hydrogen concentration several days before earthquake, at a very long distance up to $680 \mathrm{~km}$ from the epicentre:

- micro-organism hydrogen production in aerobic and anoxic conditions. For the anoxic conditions the following processes are possible: fermentation of organic material, nitrogen fixation, carbon monoxide oxidation, phosphide oxidation, acetate oxidation (Gregory et al., 2019).

Others mechanisms seems realistic or possible but not clearly observed or demonstrated for subsurface (some hundreds of meters deep):

- degassing of primordial hydrogen (Larin, 1993);

- hydro-oxidation of $\mathrm{Fe}^{2+}$ of siderite at moderate temperature Milesi et al. (2015) demonstrate that the reaction is possible but at high temperature and high pressure;

- hydro-oxidation of pyrite. This mineral is very stable and no hydro-oxidation (without oxygen) has been reported (Toniazzo, 1998);

- hydro-oxidation of $\mathrm{Fe}^{2+}$ in biotite. This reaction is currently studied by J. Murray, B. Fritz et al. with real data of the granite of Soulz-sous-Forêts. It is possible but will produce significant quantities of hydrogen only if the hydrogen is regularly withdrawn from the system;

- reaction of $\mathrm{H}_{2} \mathrm{~S}$ with $\mathrm{FeS}$ (pyrrhotite) leading to pyrite formation and $\mathrm{H}_{2}$ released (Drobner et al., 1990);

$-\mathrm{H}_{2}$ generation by thermogenesis from organic matter, is not considered, based on the shale gas production. Hydrogen is quite never recorded. The best value is $0.07 \%$ in Barnett shale (Johnson et al., 2015).

Others mechanisms have been observed in industrial contexts but they seem unrealistic in situ because of the elements or the level of energy they need:

- manufacturing gas from coal or wood;

- hydro-oxidation of iron metal (Fe) with a high temperature (chemical reaction which lead to discover $\mathrm{H}_{2}$ gas by Lavoisier);

- generation of $\mathrm{H}_{2}$ while an iron tool is acting in water, needing high energy (while drilling or grinding rocks) (Bjornstad et al., 1994);

- reaction of acid $\left(\mathrm{H}_{2} \mathrm{SO}_{4}\right.$ for instance) on iron powder (the process used to prepare $\mathrm{H}_{2}$ for airship balloons during early 20th century (Bidault des Chaumes, 1914) or leading to corrosion of steel equipment;

- methane pyrolysis $\left(\mathrm{CH}_{4}>>\mathrm{C}+2 \mathrm{H}_{2}\right)$. This reaction has been recently improved by catalysis and proposed as a process to manufacture hydrogen at $600{ }^{\circ} \mathrm{C}$ (Upham et al., 2017);

- pyrolysis of oil shale (like Colorado oil shale) at $510^{\circ} \mathrm{C}$ gives better generation rate for hydrogen than for methane (Burnham, 2010);

- more over $\mathrm{H}_{2}$ may be generated by oxygen corrosion of steel (containing $\mathrm{Fe}$ ) equipment or similar effects due to cathodic protection (corrosion of the anode or generation of $\mathrm{H}_{2}$ in case of too high potential applied to the equipment).

\subsubsection{Possible mechanisms for Vaux $\mathrm{H} 2$ generation}

The origin of the hydrogen of Vaux-en-Bugey field is not clear. Isotopic data should help to confirm some hypothesis but they are not available. Based on the geologic knowledge of one of the most studied area in France, the Jura, several hypotheses are proposed among the list presented above:

- hydro-oxidation of $\mathrm{Fe}^{2+}$ of minerals was the first tentative interpretation. No ultrabasic rocks (with concentrations of divalent iron $\mathrm{Fe}^{2+}$ ) which could produce hydrogen in the crust are reported around Vaux location. The basement is a standard igneo-metamorphic type basement. Texas and Mali case studies have Precambrian rocks nearby, not in Vaux-en-Bugey area;

- iron mines have been operated nearby (Mazenot, 1936), in Villebois for instance, and ferruginous oolithic Toarcian facies is confirmed in well Torcieu $(20 \mathrm{~m}$ above the decollement plane). But the data available on this Liasic ferrous horizon, (Cayeux, 1922) show only $\mathrm{Fe}^{3+}$ components as hematite. In other iron mines of the same horizon, Western (Mont Du Lyonnais province) or Southern (Isere province) siderite $\left(\mathrm{FeCO}_{3}\right)$ is reported (Cayeux, 1922) as component of the cement between oolites. Thus, it is not totally impossible that siderite does exist in Toarcian ferrous horizon and had been oxidized to provide $\mathrm{H}_{2}$ to Vaux field but it is not very probable;

- as position and composition of granite within the basement is unknown in the area, the biotite hydro-oxidation process remains possible along deep basement faults but not documented; 
- the deep crustal outgassing of $\mathrm{H}_{2}$ along faults is a possible mechanism as deep faults provide communication between deep crust and Vaux formation. The hydrogen migration from deep crust could have started very early along old Hercynian faults reactivated by Oligocene distension or alpine inversion during late Miocene and possibly ongoing;

- the radiolytic process (due to radioactive decay) is possible. It would probably be linked with the helium formation and migration from deep crust mentioned above. Lin et al. (2005) proposed a cross-plot between He content and $\mathrm{H}_{2}$ content in subsurface water. A line is drawn for a pure radiolytic generation and different spots representing different geological contexts where Helium and $\mathrm{H}_{2}$ has been measured.

Calculating a $\mathrm{H}_{2}$ and $\mathrm{He}$ water content from the content in the gas ( 5 and $0.096 \%)$, the pressure of the field $(30 \mathrm{~b})$ and the respective Henry constants $\left(5.10^{7}\right.$ and $\left.10^{8}\right)$, the dot corresponding to Vaux formation water $\left(\mathrm{H}_{2}=8.10^{6} \mu \mathrm{mol} /\right.$ $\mathrm{L}$ and $\left.\mathrm{He}=3.2 \cdot 10^{5} \mu \mathrm{mol} / \mathrm{L}\right)$ takes perfectly place in the high corner of the plot, not far from the radiolytic/ radiogenic production trend. This fact is consistent with a radiolytic generation of hydrogen and radiogenic generation of helium from the same source.

- reaction of water with ${ }^{40} \mathrm{Ca}$, should be considered. This effect is probably the origin of hydrogen contained in North Germany gas fields due to Zechstein salt (Gregory et al., 2019) but is not probable for Vaux-en-Bugey because the Keuper does not contain apparently potassic mineral (as sylvinite);

- anaerobic fermentative hydrogen production in the reservoir is not very probable: since organic content of the dolomite reservoir is supposed to be poor, a biogenic generation of methane is excluded (refer Sect. 3.1);

- steel corrosion effect cannot explain $\mathrm{H}_{2}$ measured at the beginning of operation or during discovery of the field (no oxygen in the subsurface, brand new casings and tubings, and no cathodic protection);

- the last mechanism to consider is frictional mechanism. Many details on the quaternary tectonic history are reported by De La Taille (2015) to emphasize the faulting activity in this active thrust belt (Fig. 5): as the Chautagne (Ambérieu) seismic event (1822), MSK intensity VII-VIII, magnitude (5.5) (Fig. 6). Also, a very superficial seismicity has been recorded in South Jura, like in Conand earthquake (near Vaux-en-Bugey, 3.7 magnitude but epicentre inbetween 1 and $2 \mathrm{~km}$ deep) (Fig. 7), and so affecting thrusted sediments. It seems established now that crustal thrusting also take place in the chain: related highest intensities are predicted up to 6.7. For Jouanne et al. (1995), induced movement of rocks in front of the Jura is estimated to be $4 \mathrm{~mm} /$ year.

According to Hirose et al. (2011), the hydrogen concentration could reach $1.1 \mathrm{~mol} / \mathrm{kg}$ of fluid. Considering a surface of $1 \mathrm{~km}^{2}$ (approximate size of the field compartment) and a thickness of $1 \mathrm{~mm}$, the number of moles of $\mathrm{H}_{2}$ that could be generated could be $1.1 \cdot 10^{6}$ to be compared to $3.10^{4}$ moles of $\mathrm{H}_{2}$ present in the field. This approximate calculation demonstrates that this mechanism seems able to explain the $\mathrm{H}_{2}$ generation in Vaux.
According to such a mechanism, a very young source of $\mathrm{H}_{2}$ is possibly ongoing. To proof this process is still operating at present time is difficult because the field gas quality has been changing during the last decades, probably due to secondary processes as described in the next chapter.

\subsection{Hydrogen sulphide}

As explained above, hydrogen sulfide was present since the discovery of the field. Now the content measured is $130 \mathrm{ppm}$. This gas could be produced by different mechanisms but specifically from $\mathrm{H}_{2}$ as described in 5.2.

\section{Discussion on recent gas quality measurements}

Well SREP5 is still available for measures and it is an opportunity to compare historical data and recent data, decades after discovery and production. This comparison is useful to understand what happens to hydrogen in the subsurface in the long term, either in natural gas fields or in artificial deposits (underground gas storage reservoirs).

\subsection{Recent gas quality measurements}

Table 2 presents recent measurements of gas quality (2018) performed by the authors on well SREP5. These measurements have been performed with BIOGAS 5000 (Geotech product, Atex certified for $\mathrm{CH}_{4}, \mathrm{O}_{2}, \mathrm{CO}_{2}, \mathrm{H}_{2} \mathrm{~S}$ ) for all gases except hydrogen and with Portasens II (Analytical Technology product certified) for hydrogen content.

The pressure at the well head SREP5 is the atmospheric pressure (according to an approximative measurement based on hydrostatic level performed by the authors).

To obtain stabilized values of $\mathrm{H}_{2}$ content (without variation within half an hour), one or two hours are needed.

The hydrogen content of the gas is lower than the initial values (Tab. 2) and it should be examined if this value is representative of the gas remaining in the reservoir.

The down hole connection between the well and the reservoir is unclear. The well is made of a 9" casing and a 7" tubing equipped with a screen is supposed to be inside the well but the annulus between both tubes is not isolated.

The $\mathrm{H}_{2}$ content measured may be due to casing-tubing corrosion. This scenario is realistic. The measurements were performed after around one hour of decreasing concentration period and half-an hour of stabilization. The gas volume produced by the well was estimated to be around $301 / \mathrm{h}$ by different methodologies: size of the flame (Etiope, 2015chapter 2$)$ and 2 types of meters giving a maximum $(40 \mathrm{l} / \mathrm{h})$ and a minimum rate $(27 \mathrm{l} / \mathrm{h})$. Gas flow with such a rate needs several hours to renew entirely the volume of the well which is around $8.8 \mathrm{~m}^{3}$ (354 $\mathrm{m}$ of tubing 7"). Such a flowing period was not possible before the measurements. Thus, it is not excluded that even stabilized, the measured $\mathrm{H}_{2}$ content is different than the concentration of the gas in the reservoir.

The initial measurement is around $0.1 \%$ higher than the stabilized measurement. As the flow is laminar in well, we could calculate that in half an hour, the 38 first $\mathrm{cm}$ of the tubing are withdrawn. The higher part of the production casing and 
the tubing (around $\mathrm{cm}$ ) are not buried and then submitted to temperature differences and condensation of water and hydrocarbon during very cold periods. This leads probably to a higher internal corrosion in this part of the well and a poor surface status. The excess of hydrogen produced during this stabilization period could be estimated to $0.0075 \mathrm{~L}$. This may correspond to hydrogen due to corrosion, considering one day of this corrosion at a rate of $2.5 \mu \mathrm{m} /$ year on $75 \mathrm{~cm}$ of 7 " tubing. This rate of internal corrosion is lower than some references of total corrosion (internal and external) on wet gas production wells (Patroni, 2007) but seems realistic according to the situation of the well.

The conclusion of these analysis is that the concentration measured may be higher than the representative concentration in the field. This possibility does not change the general conclusion drawn from these new data:

- $\mathrm{CO}_{2}$ content is similar to the historical values (around 5\%);

$-\mathrm{H}_{2}$ (hydrogen) content has decreased to around $0.5 \%$ or even less if the corrosion scenario described above has to be considered.

\subsection{Discussion on the evolution of hydrogen content}

To interpret this change in hydrogen content, several hypotheses could be proposed.

The first point to clarify is the homogeneity of this concentration in the gas field. The recent data are measured on the well SREP5. The value of $5 \% \mathrm{H}_{2}$ correspond to the well SREP2 and the value measured on well Pagniez Bregi was $3.7 \%$. We do not have any information on the measure $(0 \%)$ given by Locherer (1927). It is the reason why doubting of it seems reasonable.

Gravity segregation of $\mathrm{H}_{2}$ in the reservoir may exist and explain these differences. Actually, the depths (below sea level) of the swallower gas layer are not varying consistently: $+148 \mathrm{~m}$ above sea-level for Well Pagniez-Bregi, $+123 \mathrm{~m}$ above sea-level for SREP2 and $+120 \mathrm{~m}$ above sea level for SREP5. On the basis of these data, this hypothesis is not confirmed.

Hydrogen could disappear in the subsurface due to biochemical reactions (Marcogaz 2016; Gregory et al., 2019). One of them is the sulphate consumption by sulphate-reducing bacteria (SRB): according to the following reaction:

$6 \mathrm{H}_{2}+\mathrm{SO}_{4}{ }^{2-}=>\mathrm{H}_{2} \mathrm{~S}+4 \mathrm{H}_{2} \mathrm{O}$

No formation water analysis is available but gypsum horizons are very close to the reservoir and thus it is very probable that the formation water contains $\mathrm{SO}_{4}$ ions.

An approximative material balance on $\mathrm{SO}_{4}$ consumed and $\mathrm{H}_{2} \mathrm{~S}$ produced confirm the feasibility of the scenario: the water formation volume, even without water influx with a reasonable $\mathrm{SO}_{4}$ concentration (some $\mathrm{mg} / \mathrm{l}$ ) could be able to supply the $\mathrm{SO}_{4}$ needed to consume the main part of the hydrogen of the field. It is possible that the major part of $\mathrm{H}_{2} \mathrm{~S}$ created had been withdrawn during production, and the remaining was dissolved in formation water but it is difficult to perform a mass-balance calculation because the initial $\mathrm{H}_{2} \mathrm{~S}$ content in the gas in unknown.

The question is to clarify when the reaction started: after gas migration to trap 2 (the Buntsandstein formation water does not contain sulphate), during gas depletion, after gas depletion?

Some $\mathrm{H}_{2} \mathrm{~S}$ was probably in the gas before the discovery of the field (see above-sulfur crystallization in reservoir cores) but the main $\mathrm{H}_{2} \mathrm{~S}$ production reaction may have start since the discovery and is contributing to $\mathrm{H}_{2}$ decrease. The drilling process may have provided SRB or feed SRB with nutriments (Gregory et al., 2019).

Another possible reaction able to consume hydrogen, is the methanogenesis:

\section{$7 \mathrm{H}_{2}+\mathrm{CO}_{2}=>\mathrm{CH}_{4}+2 \mathrm{H}_{2} \mathrm{O}$}

This reaction is possible at high temperature. This reaction is suspected to be possible at low temperature due to bacteria. (Buzek et al., 1994; Panfilov, 2010; Gregory et al., 2019; Ranchou-Peyruse et al., in press). If this reaction had happened in Vaux-en-Bugey reservoir, the $\mathrm{CO}_{2}$ content would have decreased. Table 2 values does not demonstrate clear decrease of $\mathrm{CO}_{2}$ content. But $\mathrm{CO}_{2}$ content in gas is directly linked to another geo-chemical equilibrium with carbonate and may change independently of methanogenesis. In conclusion, the methanogenesis reaction is not demonstrated but not totally excluded.

\section{Conclusion}

The case study of Vaux-en-Bugey field would contribute to a better understanding of natural hydrogen origin and geochemical mechanisms when stored in the underground.

Even in a well-known geological context as Jura is, the origin of hydrogen in the gas remains uncertain. Vaux-enBugey appears to be a case of hydrogen accumulation in continental crust which is not linked with a nearby ophiolite serpentinization mechanism which is the main described one.

Several hypotheses have been considered. According to the authors the more probable mechanism is water radiolysis for hydrogen and radiogenic origin for helium, from deep basement source (or possibly nearby Autunian hot shales) migrating along old and still active Hercynian faults. The other probable mechanism is mechano-radical hydrogen generation, cataclasis, due to friction along shallow or deep faults.

Timing of the gas reservoir infilling could not be solved properly. Nevertheless, the authors prevail a better probability for gas charge happened during thrusting, which allowed migration from a former gas accumulation in Buntsandstein.

Isotopic analysis of hydrogen in $\mathrm{CH}_{4}, \mathrm{H}_{2}$ and of associated He would give useful data.

Recent analysis of the gas strongly suggest that the hydrogen content has decreased since the discovery of the field, a century ago. The corresponding mechanism is probably the consumption by SRB (sulphato-reducing-bacteria). Water analysis and geochemical reservoir modelling would confirm this hypothesis.

\section{Supplementary Material}

Figure S1. Seismic profiles (Rocher et al., 2004).

Figure S2. Torcieu well field log, 1917-1919 (St Gobain archives). 
Figure S3. Vaux-en-Bugey wells location map, 1924 (ENS Lyon archives).

The Supplementary Material is available at http://www.bsgf.fr/ $10.1051 / \mathrm{bsgf} / 2020005 / \mathrm{olm}$.

Acknowledgements. The authors thank Mr J. Reverdy for his kindness to introduce them to Vaux-en-Bugey gas field history and for his help on site.

They thank Saint-Gobain Archives to provide original unpublished data (Torcieu well field log. Fig. S2) and G. Dromart for providing historical documents on the field (Fig. S3).

They thank P. Houel and R. Vially for discussions and support.

\section{References}

Angino EE, Zeller EJ, Dreschhoff GAM, Goebel ED, Coveney RMJ. 1990. Spatial distribution of hydrogen in soil gas in central Kansas, USA. In: Geochemistry of gaseous elements and compounds. Athens (Greece): Theophratus Publishers, pp. 485-493.

Ballentine CJ, Lollar BS. 2002. Regional groundwater focusing of nitrogen and noble gases into the Hugoton-Panhandle giant gas field, USA. Geochimica et Cosmochimica Acta 66(14): 2483-2497.

Bergerat F, Mugnier JL, Guellec S, Truffert C, Cazes M, Damotte B et al. 1990. Extensional tectonics and subsidence of the Bresse Basin: An interpretation from ECORS data. Mémoires de la Société géologique de France 156: 145-156.

Bidault des Chaumes A. 1914. La fabrication de l'hydrogène pour le gonflement des ballons militaires en France et en Allemagne. Le Génie Civil 1685: 401-407. Available from https://gallica.bnf.fr/ (last consult. 2019/08/22).

Bjornstad BN, McKinley JP, Stevens TO, Rawson SA, Fredrickson JK, Long PE. 1994. Generation of hydrogen gas as a result of drilling within the saturated zone. Groundwater Monitoring \& Remediation 14(4): 140-147.

Blanc G, Doligez B, Lajat D, Mascle A. 1991. Evaluation du potentiel pétrolier des formations paleozoiques de la Bresse et de sa bordure jurassienne, France. Bulletin de la Société géologique de France 162(2): 409-422.

Bonte A. 1948. Rapport de visite aux sondages de Vaux-en-Bugey, BRGG-A0138. Available from http://infoterre.brgm.fr/rapports/ BRGG-A0138.pdf (last consult 2019/08/31).

Bregi L. 1909. Présence de gaz naturel dans un sondage à Vaux (Ain). Annales de la Société géologique du Nord. L.XXXVIII: 23-27. Available from http://ficheinfoterre.brgm.fr/InfoterreFiche/ ficheBss.action?id=BSS001SDBN (last consult. 2019/08/31).

BRGM, ADEME. 2008. Evaluation du potentiel géothermique du réservoir clastique «Buntsandstein» du bassin bressan. Rapport final. BRGM/RP-56462-FR. Available from http://infoterre.brgm. fr/rapports/RP-56462-FR.pdf (last consult. 2019/08/31).

Brown AA. 2010. Formation of high helium gases: A guide for explorationists. Available from http://www.searchanddiscovery. com/pdfz/documents/2010/80115brown/ndx_brown.pdf.html (last consult. 2019/08/23).

Bureau Central Sismologique Français. 2006. Séisme d'Ambérieu-enBugey (dép.01) du 11 janvier 2006. Rapport préliminaire. Available from http://www.franceseisme.fr/donnees/intensites/2006/ 060111 1032/RapportBCSF_060111.pdf(last consult. 2019/08/31).
Burnham AK. 2010. Chemistry and kinetics of oil shale retorting. In: Oil shale: A solution to the liquid fuel dilemma, American Chemical Society, pp. 115-134.

Buzek F, Onderka V, Vančura P, Wolf I. 1994. Carbon isotope study of methane production in a town gas storage reservoir. Fuel 73(5): 747-752.

Byrne DJ, Barry PH, Lawson M, Ballentine CJ. 2018. Noble gases in conventional and unconventional petroleum systems. Geological Society, London, Special Publications, 468(1): 127-149.

Cayeux L. 1922. Les minerais de fer oolithique de France. Paris: Imprimerie Nationale.

Charpy L. 1990. Sous le charme de Vaux-en-Bugey. Vaux en Bugey: Foyer rural de Vaux-en-Bugey.

Chiron JC, Kerrien Y. 1979. Carte géologique de la France 1:250 000, Feuille 29 Lyon. Bureau de Recherches Géologiques et Minières (Orléans, France).

Crossey LJ, Karlstrom KE, Springer A, Newell D, Hilton DR, Fischer T. 2009. Degassing of mantle-derived $\mathrm{CO}_{2}$ and $\mathrm{He}$ from springs in the southern Colorado Plateau region-Neotectonic connections and implications for groundwater systems. Geological Society of America Bulletin 121(7-8): 1034-1053.

Debrand-Passard S, Courbouleix S, Lienhardt MJ. 1984. Synthèse géologique du sud-est de la France. Mém. Bull. Rech. Géol. Minières (Orléans) 125: 615.

De La Taille C. 2015. Évaluation de l'activité tectonique quaternaire des failles du Jura Méridional (France). Doctoral dissertation, Université Grenoble Alpes.

Deville E, Prinzhofer A, Pillot D, Vacquand C, Sissman O. 2010. Peridote-water interaction generating migration pathways of $\mathrm{N}_{2}$ $\mathrm{H}_{2}-\mathrm{CH}_{4}$-rich fluids in subduction context: Common processes in the ophiolites of Oman, New-Caledonia, Philippines and Turkey. In : Eos Transactions, American Geophysical Union, Fall Meeting 2010, Abstract\# T13A-2184D.

Drobner E, Huber H, Wächtershäuser G, Rose D, Stetter KO. 1990. Pyrite formation linked with hydrogen evolution under anaerobic conditions. Nature 346(6286): 742.

Dromart G, Monier P, Curial A, Moretto R, Guillocheau F 1994. Triassic transgressive-regressive cycles in the Bresse-Jura and adjacent Basins, eastern France. In: Hydrocarbon and petroleum geology of France. Berlin, Heidelberg: Springer, pp. 347-360.

Etiope G. 2015. Natural gas seepage. The earth's hydrocarbon degassing. Cham, Heidelberg, New York, Dordrecht, London: Springer.

Etiope G, Schoell M. 2014. Abiotic gas: Atypical, but not rare Elements 10(4): 291-296.

Gage BD, Driskill DL. 2003. Helium resources of the United States. Available from http://digitalcommons.unl.edu/usblmpub/13 (last consult 2019/08/26).

Glangeaud L. 1953. Tectonique comparée des nappes de glissement dans le Jura Bressan et diverses régions méditerranéennes. Bulletin de la Société géologique de France III-44: 697-702.

Gregory SP, Barnett MJ, Field LP, Milodowski AE. 2019. Subsurface microbial hydrogen cycling: Natural occurrence and implications for industry. Microorganisms 7(2): 53.

Grellet B, Combes P, Granier T. 1993. Sismotectonique de la France métropolitaine dans son cadre géologique et géophysique: avec atlas de 23 cartes au $1 / 4000000^{\mathrm{e}}$ et une carte au $1 / 1000000^{\mathrm{e}}$ (Vol.2). Société géologique de France.

Gudefin H. 1980. Région de l'Est lyonnais. Aperçu géologique d'après les forages profonds. BRGM 79 SGN 596 RHA. Available from http://infoterre.brgm.fr/rapports/79-SGN-596-RHA.pdf (last consult 2019/08/31). 
Guellec S, Lajat D, Mascle A, Roure F, Tardy M. 1990. Deep seismic profiling and petroleum potential in the western Alps: Constraints with ECORS data, balanced cross-sections and hydrocarbon modeling. In: The potential of deep seismic profiling for hydrocarbon exploration, pp. 425-437.

Hirose T, Kawagucci S, Suzuki K. 2011. Mechanoradical $\mathrm{H}_{2}$ generation during simulated faulting: Implications for an earthquake-driven subsurface biosphere. Geophysical Research Letters 38(17).

IFP. 2002. Southern Jura. Regional report. Rueil-Malmaison: IFP-CGG. Jeandel E. 2008. Monitoring géochimique par couplage entre les gaz rares et les isotopes du carbone: étude d'un réservoir naturel. Doctoral dissertation. Available from https://tel.archives-ouvertes. fr/ (last consult. 2019/08/26).

Johnson K, Spiezo M, Wong T. 2015. Shale gas to ethylene. Available from https://processdesign.mccormick.northwestern.edu/index. php/Shale_Gas to_Ethylene_(G2) (last consult. 2019/08/26).

Jouanne F. 1994. Mesure de la déformation actuelle des Alpes occidentales et du Jura par comparaison de données géodésiques historiques. Thèse de doctorat. Mém. Sci. Terre, Univ. de Savoie.

Jouanne F, Ménard G, Jault D. 1994. Present-day vertical deformation of the French northwestern Alps/Southern Jura Mountains: comparison between historical triangulations. Geophys J Int 119: $151-165$.

Jouanne F, Ménard G, Darmendrail X. 1995. Present-day vertical displacements in the north-western Alps and southern Jura Mountains: Data from leveling comparisons. Tectonics 14(3): 606-616.

Kerrien Y, Monjuvent G. 1990. Notice explicative de la feuille Belley (1/50 000). Orléans, France: Éditions du BRGM.

Larin N. 1993. Hydridic Earth: The new geology of our primordially hydrogen-rich planet. In : Warren Hunt C, ed. Calgary, Alberta, Canada: Polar Publishing.

Larin N, Zgonnik V, Rodina S, Deville E, Prinzhofer A, Larin VN et al. 2015. Natural molecular hydrogen seepage associated with superficial rounded depressions on the European craton in Russia. Natural Resources Research 24(3): 369-383.

Lepape A. 1958. Les gaz rares in Nouveau traité de chimie minérale de P. Pascal-Tome XII. Paris : Masson, pp. 113-178.

Lin LH, Hall J, Lippmann-Pipke J, Ward A, Ward A, Sherwood Lollar B, DeFlaun $\mathrm{M}$ et al. 2005. Radiolytic $\mathrm{H}_{2}$ in continental crust: nuclear power for deep subsurface microbial communities. Geochemistry, Geophysics, Geosystems 6(7): 1-13.

Littke R, Krooss B, Idiz E, Frielingsdorf J. 1995. Molecular nitrogen in natural gas accumulations: Generation from sedimentary organic matter at high temperatures. AAPG bulletin 79(3): 410-430.

Locherer J. 1927, Les sources de gaz naturels en France. Le gisement de Vaux-en-Bugey (Ain). Le Génie Civil XC(4) 2319: 99-102. Available from https://gallica.bnf.fr (last consult. 2019/08/31).

Madritsch H, Fabbri O, Schmid S. 2011. La chaîne plissée du Jura: évidences morphologiques en faveur d'une activité post-Pliocène et discussion du contexte géodynamique actuel. Géochronique 117: 41-44.

Malvoisin B. 2013. Conditions réductrices associées à la serpentinisation: suivi magnétique de l'hydratation de l'olivine de San Carlos, étude de cas naturels et application à la production industrielle d' $\mathrm{H}_{2}$. Doctoral dissertation, Grenoble.

Marcogaz. 2016. Guidance of hydrogen/natural gas admixtures in underground gas storage facilities. Available from https://www. marcogaz.org/publications-1/documents/ (last consult. 2019/08/31).

Mariton D. 1981. Bassin houiller du bas Dauphiné : essai de synthèse. BRGM 80 SGN 674 GEO. Available from http://infoterre.brgm.fr/ rapports/80-SGN-674-GEO.pdf.
Mazenot G. 1936. Les ressources minérales de la région lyonnaise. Géocarrefour 12(2): 123-258.

Milesi V, Guyot F, Brunet F, Richard L, Recham N, Benedetti M et al. 2015. Formation of $\mathrm{CO}_{2}, \mathrm{H}_{2}$ and condensed carbon from siderite dissolution in the $200-300^{\circ} \mathrm{C}$ range and at $50 \mathrm{MPa}$. Geochimica et Cosmochimica Acta 154: 201-211.

Nivin VA. 2016. Free hydrogen-hydrocarbon gases from the Lovozero loparite deposit (Kola Peninsula, NW Russia). Applied Geochemistry 74: 44-55.

Panfilov M. 2010. Underground storage of hydrogen: in situ selforganisation and methane generation. Transport in Porous Media 85(3): 841-865.

Patroni JM. 2007. Lifetime of a natural gas storage well assessment of well-field maintenance cost. Oil \& Gas Science and TechnologyRevue de l'IFP 62(3): 297-309.

Pfiffner OA. 2014. Geology of the Alps. John Wiley \& Sons.

Philippe Y. 1994. Transfer zone in the Southern Jura thrust belt (Eastern France): Geometry, development, and comparison with analogue modeling experiments. In: Hydrocarbon and petroleum geology of France. Berlin, Heidelberg: Springer, pp. 327-346.

Philippe Y. 1995. Rampes latérales et zones de transfert dans les chaînes plissées : géométrie, condition de formation et pièges structuraux associés. Doctoral dissertation, Université de Savoie, Chambéry.

Prinzhofer A, Deville E. 2015. Hydrogène naturel. La prochaine révolution énergétique? Belin.

Prinzhofer A, Cissé CST, Diallo AB. 2018. Discovery of a large accumulation of natural hydrogen in Bourakebougou (Mali). International Journal of Hydrogen Energy 43(42): 19315-19326.

Prinzhofer A, Moretti I, Francolin J, Pacheco C, d'Agostino A, Werly J et al. 2019. Natural hydrogen continuous emission from sedimentary basins: The example of a Brazilian $\mathrm{H}_{2}$-emitting structure. International Journal of Hydrogen Energy 44(12): 5676-5685.

Pullan CP, Berry MA. 2019. Paleozoic-sourced oil play in the Jura Mountain of France and Switzerland. In : Monaghan AA, Underhill JR, Hewett AJ, Marshall JEA, eds. Paleozoic Plays of NW Europe. Geological Society, Special Publication 471, pp. 365-387.

Ranchou-Peyruse M, Auguet JF, Mazière C, Restrepo-Ortiz CX, Guignard M, Dequidt D et al. Geological gas-storage shapes deep life. Environmental Microbiology (in press), Wiley-Blackwell.

Ricour J. 1956. Le chevauchement de la bordure occidentale du Jura sur la Bresse dans la région de Lons-Le Saunier. Bull. Ver. Schweizer Petrol. Geol. und Ing 23(64): 57-70.

Rocher M, Cushing M, Lemeille F, Baize S. 2004. L'île Crémieu (Jura, France), un plateau calcaire épargné par la tectonique? Comptes Rendus Geoscience 336(13): 1209-1218.

Schoeffler J. 1941. Les sondages aux gaz de Vaux-en-Bugey. Annales des mines françaises T17: 205-252. Available from https://gallica. bnf.fr (last consult. 2019/08/31).

Sokolov V. 1974. Géochimie des gaz naturels. Moscou: Edition MIR.

Sugisaki R, Ido M, Takeda H, Isobe Y, Hayashi Y, Nakamura N et al. 1983. Origin of hydrogen and carbon dioxide in fault gases and its relation to fault activity. TheJournal of Geology 91(3): 239-258.

Toniazzo V. 1998. Approche des mécanismes d'oxydation de la pyrite par thiobacillus ferrooxidans grâce à la modélisation morphochimique de la surface minérale: rôle fondamental des phases superficielles oxydées. Doctoral dissertation, Nancy 1.

Truffert C, Burg JP, Cazes M, Bayer R, Damotte B, Rey D. 1990. Structures crustales sous le Jura et la Bresse: contraintes 
sismiques et gravimétriques le long des profils ECORS BresseJura et Alpes II. Mémoires de la Société géologique de France 156: $157-164$.

Upham DC, Agarwal V, Khechfe A, Snodgrass ZR, Gordon MJ, Metiu $\mathrm{H}$ et al. 2017. Catalytic molten metals for the direct conversion of methane to hydrogen and separable carbon. Science 358(6365): 917-921.
Vincienne H. 1932. La structure en écailles de la région d'Ambérieu et l'âge des derniers mouvements jurassiens. CR Acad. Sci. (Paris) 195: 258 .

Wang B, Liu Y, Sun X, Ma Y, Zhang L, Ren H et al. 2018. Hydrogeological and geochemical observations for earthquake prediction research in China: A brief overview. Pure and Applied Geophysics 175(7): 2541-2555.

Cite this article as: Deronzier J-F, Giouse H. 2020. Vaux-en-Bugey (Ain, France): the first gas field produced in France, providing learning lessons for natural hydrogen in the sub-surface? BSGF - Earth Sciences Bulletin 191: 7. 